\title{
High Carotenoid Mutants of Chlorella vulgaris Show Enhanced Biomass Yield under High Irradiance
}

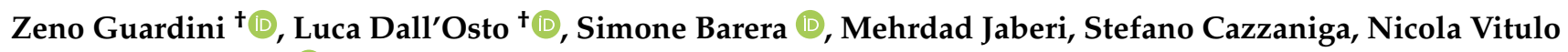 \\ and Roberto Bassi *iD
}

Citation: Guardini, Z.; Dall'Osto, L.; Barera, S.; Jaberi, M.; Cazzaniga, S.; Vitulo, N.; Bassi, R. High Carotenoid Mutants of Chlorella vulgaris Show Enhanced Biomass Yield under High Irradiance. Plants 2021, 10, 911. https://doi.org/10.3390/ plants10050911

Academic Editor: Tomoko Shinomura

Received: 5 April 2021

Accepted: 27 April 2021

Published: 1 May 2021

Publisher's Note: MDPI stays neutra with regard to jurisdictional claims in published maps and institutional affiliations.

Copyright: (c) 2021 by the authors. Licensee MDPI, Basel, Switzerland. This article is an open access article distributed under the terms and conditions of the Creative Commons Attribution (CC BY) license (https:/ / creativecommons.org/licenses/by/ $4.0 /)$.
Dipartimento Di Biotecnologie, Università Di Verona, Strada Le Grazie 15, 37134 Verona, Italy; zeno.guardini@univr.it (Z.G.); luca.dallosto@univr.it (L.D.); simone.barera@univr.it (S.B.); mehrdad.jaberi@univr.it (M.J.); stefano.cazzaniga@univr.it (S.C.); nicola.vitulo@univr.it (N.V.)

* Correspondence: roberto.bassi@univr.it; Tel.: +39-045-802-7916

+ These authors contributed equally to this work.

\begin{abstract}
Microalgae represent a carbon-neutral source of bulk biomass, for extraction of high-value compounds and production of renewable fuels. Due to their high metabolic activity and reproduction rates, species of the genus Chlorella are highly productive when cultivated in photobioreactors. However, wild-type strains show biological limitations making algal bioproducts expensive compared to those extracted from other feedstocks. Such constraints include inhomogeneous light distribution due to high optical density of the culture, and photoinhibition of the surface-exposed cells. Thus, the domestication of algal strains for industry makes it increasingly important to select traits aimed at enhancing light-use efficiency while withstanding excess light stress. Carotenoids have a crucial role in protecting against photooxidative damage and, thus, represent a promising target for algal domestication. We applied chemical mutagenesis to Chlorella vulgaris and selected for enhanced tolerance to the carotenoid biosynthesis inhibitor norflurazon. The NFR (norflurazon-resistant) strains showed an increased carotenoid pool size and enhanced tolerance towards photooxidative stress. Growth under excess light revealed an improved carbon assimilation rate of NFR strains with respect to WT. We conclude that domestication of Chlorella vulgaris, by optimizing both carotenoid/chlorophyll ratio and resistance to photooxidative stress, boosted light-to-biomass conversion efficiency under high light conditions typical of photobioreactors. Comparison with strains previously reported for enhanced tolerance to singlet oxygen, reveals that ROS resistance in Chlorella is promoted by at least two independent mechanisms, only one of which is carotenoid-dependent.
\end{abstract}

Keywords: microalgae; biomass; photoprotection; carotenoids; photooxidative stress; chloroplast; norflurazon

\section{Introduction}

Mass culture of microalgae in photobioreactors (PBRs) has gained interest in the past few decades. Beside small-scale traditional cultivations mainly aimed to human or animal feeding, commercial production of algae on a large scale has been identified as a renewable and environmentally sustainable strategy for feedstock production [1]. Both microalgae and land plants catalyze photosynthetic reactions [2], yet the simpler structure of microalgae enhances efficiency in solar energy conversion into biomass respect to plants [3-6]. Thus, cultivation of microalgae represents a promising source of biomass for many industrial applications, which include production of bioactive compounds, recombinant proteins, livestock feed, biofuels, organic fertilizer and biostimulants [7,8]. Microalgae can grow in wastewater on marginal lands, thus avoiding competition for both arable land and water source with food crops [9]. Furthermore, the high capacity for nitrogen and phosphorus removal, together with use of flue gas as a source of $\mathrm{CO}_{2}$, makes phycoremediation a valuable circular-economy-based biorefinery $[10,11]$. 
The genus Chlorella includes fast-growing species, highly productive and easy to cultivate, exploited to a significant extent as food additives and nutraceuticals [12]. Carotenoids (Car) are currently the most important commercial product from microalgae successfully marketed [13-15]. These pigments are widely utilized as aquaculture feed additives, food colorants and ingredients for cosmetics; moreover, Car have biomedical applications, as anti-inflammatory agents due to their strong antioxidant properties [1]. Xanthophylls (oxygenated Car) are antioxidants with a key role in protecting from ocular oxidative damage [16]; indeed, the human macula lutea are rich in lutein and zeaxanthin, which help maintain eye health. $\beta$-carotene is commercially produced mainly from the halophilic alga Dunaliella salina through cultivation in ponds; however, microalgae are not yet used as a source of xanthophylls at an industrial scale [7]. The latter and many other algae-based production processes require significant improvements in the high cost for PBRs management and in the efficiency at various process steps such as biomass recovery and product extraction [17]. Moreover, limitations include biological constraints such as low efficiency of PAR (photosynthetically active radiation) utilization, especially under excess light (EL) conditions, which hinder the economic viability of algal products. The maximum theoretical efficiency of solar energy conversion into biomass has been reported to fall between $6 \%$ and $12 \%[3,18]$ while present-day production systems typically exhibit photosynthetic conversion efficiency of about $1 \%$ or below $[18,19]$. Limits in biomass yield can be ascribed to a number of factors $[20,21]$, including inhomogeneous light distribution within a mass culture and photooxidative stress.

In particular, PAR efficiently drives photosynthesis under light-limiting conditions, while photoinhibition is observed upon exposure to irradiance exceeding plant capacity for electron transport, decreasing light-to-biomass conversion efficiency [22]. The high optical density of wild-type strains accounts for additional efficiency drop: a high chlorophylls (Chl) content per cell is a valuable trait which maximizes the photon capture in the natural environment, while a large array of antenna complexes (light-harvesting complexes, LHCs) [23], binding Chl and Car [24], hampers biomass productivity in a PBR. Indeed, high cell concentration originates a steep light gradient which leaves inner cell layers below the compensation point [25], while sustained over-excitation of cells in the surface layers increases the yield of $\mathrm{Chl}$ triplet state $\left({ }^{3} \mathrm{Chl}^{*}\right)$ and the consequent release of the reactive oxygen species (ROS) singlet oxygen $\left({ }^{1} \mathrm{O}_{2}\right)$. Photooxidative stress is a consequence of the formation of strongly oxidizing intermediates in different steps of the photosynthetic process, that inevitably leads to PSII photoinhibition and reduces net assimilation [26,27].

Domesticating microalgae for higher productivity in mass cultures requires introduction of traits aimed to relieve the light-use constraints [28]. Among many, we chose two traits: (i) the optical density of algal cells and (ii) the photoprotection capacity. Decreasing overall absorption of PAR per unit volume of culture was shown to enhance light distribution in PBR and thus productivity [29]. Whereas, increasing resistance to photooxidative stress is expected to prevent photoinhibition, thus increasing fitness [30] and enhancing carbon gain [31].

In the photosynthetic membranes, the photoprotective action of Car is well-established $[32,33]$. Car participate in the antioxidant network of the chloroplast, aimed at the detoxification of ROS generated by light reactions: Car efficiently act by scavenging both $\mathrm{O}_{2}{ }^{-}$and $\mathrm{OH}$, and ${ }^{1} \mathrm{O}_{2}$ in thylakoids, thus preventing lipid peroxidation. Chl-binding complexes are protected against ${ }^{1} \mathrm{O}_{2}$ formation by Car, which catalyze quenching of ${ }^{3} \mathrm{Chl}{ }^{*}$ and results in Car triplets $\left({ }^{3} \mathrm{Car}^{*}\right)$ formation, that safely decay to the ground state, producing heat $[34,35]$. Car biosynthesis is therefore a promising target to improve tolerance to photooxidative stress.

In this work, we report on the isolation of Chlorella vulgaris mutant strains combining lower optical density and higher resistance to EL stress. Through chemical mutagenesis followed by selection on the carotenoid biosynthesis inhibitor norflurazon, we succeeded in the isolation of two pale green strains enriched in the antioxidant Car (NFR, norflurazonresistant strains). Mutants exhibited higher biomass productivity in PBR, and were significantly more resistant to photooxidative damage than WT strain under very strong 
irradiance. Moreover, NFR strains in PBR showed further enhancement in productivity with respect to another Chlorella pale green mutant [36].

Overall, these results demonstrate that domestication of $C$. vulgaris for improved tolerance to photooxidation has the potential to generate strains with positive advantages in the artificial environment of a PBR. Moreover, comparison with strains previously obtained [36], which were selected for resistance to ${ }^{1} \mathrm{O}_{2}$, reveals that photoprotection in Chlorella is promoted by at least two independent mechanisms, only one of which is strengthened by Car overaccumulation.

\section{Results}

\subsection{Isolation of NFR-3 and NFR-13, High Car Content Mutants of Chlorella vulgaris}

Tolerance to high light stress is a desired trait for microalgal biotechnology [37], being crucial for establishing efficient outdoor cultivation in low latitudes. Car biosynthesis represents an obvious target when aiming to enhance photosynthetic yield of microalgae under photooxidative conditions caused by EL. Indeed, Car contribute to the antioxidant network of the chloroplast, aimed to the detoxification of ROS, particularly ${ }^{1} \mathrm{O}_{2}$ generated by photosynthetic light reactions, thus preventing lipid peroxidation [38], whereas the photoacclimation to high light involves Car up-regulation [39]. We used random mutagenesis and phenotypic screening to isolate $C$. vulgaris strains that combined a pale green phenotype with increased size of Car pool, these being traits expected to improve light conversion efficiency. Cells were subjected to two rounds of random chemical mutagenesis with EMS and mutants were selected for resistance to norflurazon, an inhibitor of carotenogenesis [40]. In a first selection step, approximately 5000 mutagenized lines were screened and seven independent mutants were distinguished as putatively affected in Chl content per cell. Pale green strains were pooled, grown to enhance cell number, and submitted to a second treatment with EMS. Approximately 60,000 mutagenized lines were spread on BG-11 agar plates containing $4 \mu \mathrm{M}$ norflurazon. 54 herbicide-resistant colonies (NFR, norflurazon-resistant) were obtained. Upon discarding mutants exhibiting either low growth or unstable resistance to the herbicide, 12 lines were selected, grown in liquid cultures, and the Car and Chl content per cell was determined after five days of growth under photoautotrophic conditions. Among the identified strains, lines NFR-3 and NFR-13 showed the highest Car content per cell, and were therefore selected for further analysis.

NFR lines showed a significant reduction of Chl content per cell $(-58 \%$ in NFR-3, $-73 \%$ in NFR-13) (Table 1). The Chl $a / b$ ratio was significantly higher in the mutants, with a value of $4.14 / 4.92$ in NFR-3/-13 vs. 2.67 in WT. These data hint a reduction in the Chl $b$ rich antenna complexes (LHC) in both mutants. Moreover, NFR-13 strain showed a stronger decrease in total $\mathrm{Chl}$ per cell and a higher $\mathrm{Chl} \mathrm{a} / \mathrm{b}$ ratio, thus suggesting that the $\mathrm{Chl} b$-enriched antenna system was further decreased in this line respect to NFR-3.

Table 1. Pigment content, PSII maximum quantum yield $\left(\mathrm{F}_{\mathrm{v}} / \mathrm{F}_{\mathrm{m}}\right)$ and PSII functional antenna size of WT and mutants NRF. Parameters were determined after 5 days of growth in minimal medium BG-11. Data are expressed as mean \pm SD, $\mathrm{n}>4$. Significantly different values (ANOVA followed by Tukey's post-hoc test at a significance level of $p<0.05$ ), within the same column, are marked with different letters.

\begin{tabular}{|c|c|c|c|c|c|}
\hline Genotype & Chl/Cell (pg) & Car/Cell (fg) & Chl $a / b$ & $\mathrm{~F}_{\mathrm{v}} / \mathrm{F}_{\mathrm{m}}$ & PSII Antenna Size $\left(\mathrm{T}_{2 / 3}{ }^{-1} \cdot 10^{3}, \mathrm{~ms}^{-1}\right)$ \\
\hline WT & $0.26 \pm 0.03^{a}$ & $57 \pm 3^{a}$ & $2.67 \pm 0.22^{a}$ & $0.67 \pm 0.03^{a}$ & $6.74 \pm 0.49^{\mathrm{a}}$ \\
\hline NFR-3 & $0.11 \pm 0.02^{b}$ & $71 \pm 3^{b}$ & $4.14 \pm 0.35^{b}$ & $0.66 \pm 0.03^{a}$ & $4.32 \pm 0.22^{b}$ \\
\hline NFR-13 & $0.07 \pm 0.01^{c}$ & $65 \pm 2^{c}$ & $4.92 \pm 0.46^{c}$ & $0.65 \pm 0.04^{\mathrm{a}}$ & $3.19 \pm 0.42^{c}$ \\
\hline
\end{tabular}

Both NFR-3 and NFR-13 exhibited higher Car content per cell $(+25 \%$ and $+14 \%$, respectively) respect to the WT strain (Table 1). Additional HPLC analysis of the Car composition of cell extracts (Table 2, Figure S1) revealed that carotenes and xanthophylls, while more abundant in NFR on a Chl basis, were maintained in similar relative abundance compared to WT. 




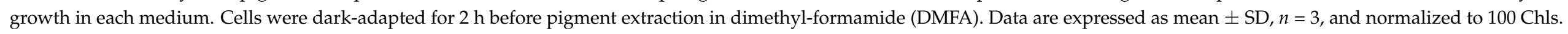
Significantly different values (ANOVA followed by Tukey's post-hoc test at a significance level of $p<0.05$ ), within the same column, are marked with different letters.

\begin{tabular}{|c|c|c|c|c|c|c|c|c|c|c|c|}
\hline & \multirow[b]{2}{*}{ Genotype } & \multirow[b]{2}{*}{ Car/Cell (fg) } & \multirow[b]{2}{*}{ Chl $a / b$} & \multirow[b]{2}{*}{ Chl/Car } & \multicolumn{7}{|c|}{ mol/100 mol Chl } \\
\hline & & & & & Neo & Viola & Anthera & Lute & Zea & $\alpha$-Car & $\beta$-Car \\
\hline \multirow{3}{*}{ Control } & WT & $57 \pm 3^{a}$ & $2.7 \pm 0.2^{a}$ & $4.3 \pm 0.1^{\mathrm{a}}$ & $2.8 \pm 0.8^{a}$ & $2.8 \pm 0.7^{a}$ & $0.1 \pm 0.1^{\mathrm{a}}$ & $13.5 \pm 1.7^{\mathrm{a}}$ & $1.3 \pm 0.1^{\mathrm{a}}$ & $0.5 \pm 0.1^{a}$ & $1.9 \pm 0.3^{\mathrm{a}}$ \\
\hline & NFR-3 & $71 \pm 3^{b}$ & $4.1 \pm 0.3^{b}$ & $1.6 \pm 0.1^{\mathrm{c}}$ & $5.3 \pm 1.3^{b}$ & $8.9 \pm 1.7^{b}$ & $1.4 \pm 0.2^{c}$ & $37.3 \pm 8.7^{c}$ & $5.8 \pm 1.1^{c}$ & $0.8 \pm 0.2^{\mathrm{a}}$ & $4.9 \pm 1.0^{b, c}$ \\
\hline & NFR-13 & $65 \pm 2^{c}$ & $4.9 \pm 0.4^{b}$ & $1.0 \pm 0.3^{\mathrm{d}}$ & $4.6 \pm 0.5^{b}$ & $15.5 \pm 3.0^{\mathrm{c}}$ & $2.0 \pm 0.5^{c, d}$ & $54.9 \pm 5.0^{\mathrm{d}}$ & $7.9 \pm 1.6^{c}$ & $1.5 \pm 0.2^{b}$ & $9.5 \pm 1.6^{\mathrm{c}, \mathrm{d}}$ \\
\hline \multirow{3}{*}{ N-depleted } & WT & $89 \pm 4^{\mathrm{d}}$ & $2.8 \pm 0.1^{\mathrm{a}}$ & $2.8 \pm 0.1^{\mathrm{e}}$ & $3.9 \pm 0.5^{b}$ & $3.1 \pm 0.4^{\mathrm{a}}$ & $1.1 \pm 0.2^{\mathrm{c}}$ & $21.5 \pm 0.3^{b}$ & $2.9 \pm 0.3^{b}$ & $0.7 \pm 0.1^{\mathrm{a}}$ & $2.9 \pm 0.1^{b}$ \\
\hline & NFR-3 & $121 \pm 2^{\mathrm{e}}$ & $4.1 \pm 0.1^{b}$ & $0.9 \pm 0.1^{\mathrm{d}}$ & $14.7 \pm 1.1^{\mathrm{d}}$ & $18.8 \pm 3.9^{\mathrm{e}}$ & $3.1 \pm 0.8^{d}$ & $52.9 \pm 1.1^{\mathrm{d}}$ & $11.2 \pm 0.8^{\mathrm{d}}$ & $1.8 \pm 0.1^{\mathrm{b}}$ & $8.4 \pm 0.1^{\mathrm{d}}$ \\
\hline & NFR-13 & $160 \pm 8^{f}$ & $4.8 \pm 0.2^{b}$ & $0.4 \pm 0.1^{\mathrm{d}}$ & $27.7 \pm 7.1^{\mathrm{e}}$ & $40.0 \pm 0.6^{f}$ & $4.7 \pm 1.7^{\mathrm{d}}$ & $116.3 \pm 2.6^{\mathrm{e}}$ & $21.9 \pm 0.4^{\mathrm{e}}$ & $2.9 \pm 0.2^{c}$ & $19.8 \pm 0.2^{\mathrm{e}}$ \\
\hline
\end{tabular}


Further to the characterization of these mutants, we checked the effect of nitrogen starvation on Car accumulation, a treatment reported to increase Car content [41]. When transferred from standard BG-11 to a modified BG-11 medium with limiting N source $\left(\mathrm{NaNO}_{3} 0.8 \mathrm{mM}\right)$, Car contents on a per cell basis increased in both NFR strains, by 1.7and 2.5-fold, respectively, than standard BG-11, with the $\beta, \beta$-xanthophylls undergoing a preferential enhancement over $\alpha, \beta$-xanthophylls and carotenes (Figures S1 and S2, Table 2).

\subsection{Stoichiometry of Pigment-Protein Complexes and Photosynthetic Efficiency}

To determine whether the mutation affected the PSII operating efficiency, Chl fluorescence measurements were carried out to quantify the capacity of the antenna system to transfer absorbed energy to RCs. All strains showed no significant differences in the maximal quantum yield of PSII photochemistry $\left(\mathrm{F}_{\mathrm{v}} / \mathrm{F}_{\mathrm{m}}\right)$ (Table 1$)$, suggesting that the PSII function was not worsened in NFR mutants despite the altered pigment composition. PSII functional antenna size was evaluated upon treatment of cells with DCMU (3-(3,4dichlorophenyl)-1,1-dimethylurea), an inhibitor that blocks the plastoquinone binding site of PSII. In DCMU-treated cells, the rise time of Chl $a$ fluorescence (Figure 1A) is inversely related to the antenna cross-section $[42,43]$. The $\mathrm{T}_{2 / 3}{ }^{-1}$ of the Chl fluorescence rise was reduced by $\sim 36 \%$ in NFR-3 and by $\sim 53 \%$ in NFR-13, with respect to WT (Table 1 ).

A

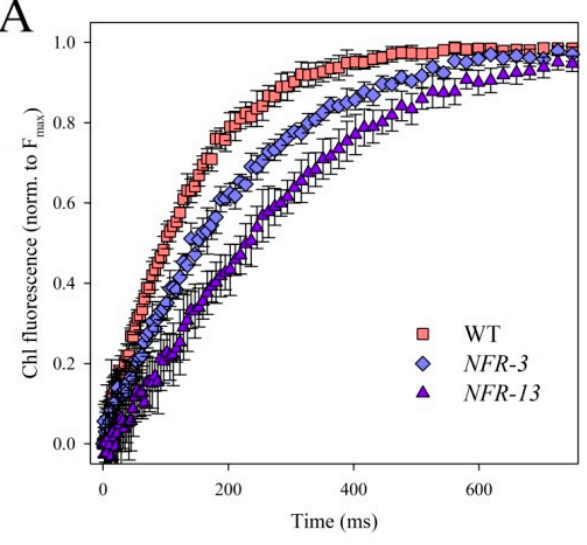

$\mathrm{C}$

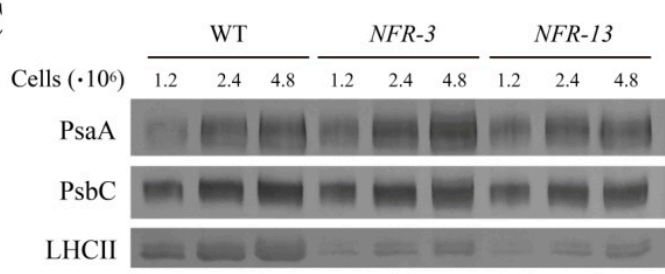

\begin{tabular}{|c|c|c|c|}
\hline & WT & $N F R-3$ & NFR-13 \\
\hline PSI / cell & $100 \pm 16^{a}$ & $134 \pm 20^{\mathrm{a}}$ & $121 \pm 29^{a}$ \\
\hline PSII / cell & $100 \pm 29^{a}$ & $83 \pm 22^{a}$ & $71 \pm 20^{\mathrm{a}}$ \\
\hline HCII / cell & $100 \pm 32^{a}$ & $34 \pm 5^{b}$ & $38 \pm 6^{b}$ \\
\hline
\end{tabular}

B



\begin{tabular}{|c|c|c|c|}
\hline & WT & $N F R-3$ & NFR-13 \\
\hline PSI / PSII & $100 \pm 11^{\mathrm{a}}$ & $146 \pm 23^{b}$ & $131 \pm 5^{b}$ \\
\hline CII / PSII & $100 \pm 9^{a}$ & $31 \pm 6^{b}$ & $32 \pm 9^{b}$ \\
\hline
\end{tabular}

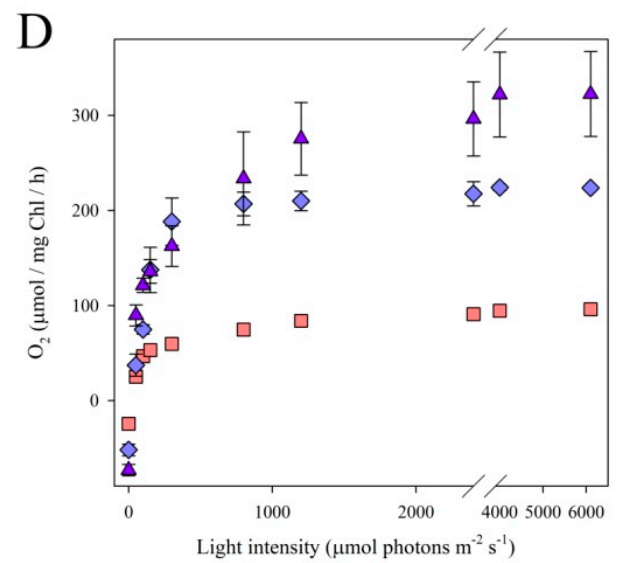

Figure 1. Characterization of C. vulgaris norflurazon-resistant (NFR) strains of Chlorella vulgaris. (A) PSII functional antenna size. Variable $\mathrm{Chl}$ fluorescence was induced with a green light $\left(15 \mu \mathrm{mol}\right.$ photons $\left.\mathrm{m}^{-2} \mathrm{~s}^{-1}\right)$, on dark-adapted cells of WT and NFR (about $1 \times 10^{7}$ cells $\mathrm{mL}^{-1}$ ) in BG-11 medium supplemented with $50 \mu \mathrm{M}$ DCMU. Data are expressed as mean \pm SD, $n=10$. The reciprocal of time needed for reaching two-thirds of the fluorescence rise $\left(\mathrm{T}_{2 / 3}\right)$ was taken as a measure of the PSII functional antenna size (see Table 1). (B,C) Immunoblotting used for the quantification of photosynthetic subunits. (upper) Immunotitration was performed with antibodies directed against individual gene products: LHCII, the major light harvesting complex of PSII; the PSII core subunit PsbC (CP43); the PSI core subunit (PsaA). The amounts of Chls (panel B) and of cells (panel C) loaded for each lane are indicated. (lower) In each table, significantly different values (ANOVA followed by Tukey's post-hoc test at a significance level of $p<0.05$ ), within the same row, are marked with different letters. (D) Light-saturation curves of photosynthesis, measured in cultures grown in BG-11 minimal medium. Data are expressed as mean $\pm S D, n=4$. 
These results were supported by quantification of LHC protein content. The abundance of selected photosynthetic subunits was assessed by immunotitration on cell extracts and expressed relative to WT, upon normalization to the PSII inner antenna CP43 content (Figure 1B). The LHCII/PSII ratio was reduced in both NFR mutants (-68\% vs. WT), while the PSI/PSII (PsaA/PsbC) ratio was significantly higher in mutants. When cultivated under limiting light conditions $\left(70 \mu \mathrm{mol}\right.$ photons $\left.\mathrm{m}^{-2} \mathrm{~s}^{-1}\right)$, both mutants showed a significant decrease in growth rate and a lower mean biomass production with respect to WT, consistent with the reduction in PSII antenna size (Figure S3).

The content in LHCII, PsbC and PsaA subunits was quantified on a per cell basis by immunotitration, and expressed as a percentage of the corresponding WT values. Figure 1C shows that LHCII content in NFR cells was significantly reduced vs. WT, while PSI and PSII contents were less affected.

The operation efficiency of the photosynthetic machinery was investigated in a wide range of irradiances, by measuring the light-saturation curve of photosynthesis in WT and NFR cells, grown under photoautotrophic conditions (Figure 1C). The rate of $\mathrm{O}_{2}$ production rose as a function of light intensity within the range 0-1000 $\mu \mathrm{mol}$ photons $\mathrm{m}^{-2} \mathrm{~s}^{-1}$, showing a linear increase for WT and NFR lines at irradiances below $150 \mu \mathrm{mol}$ photons $\mathrm{m}^{-2} \mathrm{~s}^{-1}$.

The linear regressions of $\mathrm{O}_{2}$ release vs. light intensity exhibited a slope of $0.71 \pm 0.07$ for WT, with a significant increase in NFR strains $(1.27 \pm 0.13$ in NFR-3, $1.94 \pm 0.29$ in $N F R-13)$, suggesting that the effective quantum yield of photosynthesis was enhanced in NFR mutants with respect to WT. Half-saturation of photosynthesis was reached at similar light intensity in WT and NFR-3 strains (approximately 110-130 $\mu \mathrm{mol}$ photons $\mathrm{m}^{-2} \mathrm{~s}^{-1}$ ), while it was significantly higher in NFR-13 strain (Table 3). Values of $\mathrm{P}_{\max }$, the maximum rate of light-induced $\mathrm{O}_{2}$ evolution (photosynthesis net respiration), was reached around $2000 \mu \mathrm{mol}$ photons $\mathrm{m}^{-2} \mathrm{~s}^{-1}$ in WT strain, with a value of $96 \pm 5 \mu \mathrm{mol} \mathrm{O}_{2} \mathrm{mg} \mathrm{Chl}^{-1} \mathrm{~h}^{-1}$; this value was significantly higher in NFR cells (225 \pm 2 in NFR-3, $323 \pm 45$ in NFR-13). $\mathrm{O}_{2}$ production rate was normalized on Chl content, yielding $\mathrm{P}_{\max }$ as a measure of the productivity for the two strains per unit $\mathrm{Chl}$. The dark respiration rate on a per cell basis was the same in WT and mutant strains (Table 3). As a whole, these results point to an enhanced photosynthetic productivity of NFR mutants with respect to the WT.

Table 3. Photosynthesis and respiration rates. Parameters were measured on dark-adapted cell suspensions of WT and NFR strains, upon 5 days of photoautotrophic growth in BG-11 medium in low light conditions $\left(70 \mu \mathrm{mol}\right.$ photons $\left.\mathrm{m}^{-2} \mathrm{~s}^{-1}, 25^{\circ} \mathrm{C}\right) . \mathrm{O}_{2}$ evolution and consumption were measured with a Clark-type oxygen electrode (Oxygraph, Hansatech UK). Data are expressed as mean $\pm \mathrm{SD}, n>4$. Significantly different values (ANOVA followed by Tukey's post-hoc test at a significance level of $p<0.05)$, within the same row, are marked with different letters.

\begin{tabular}{cccc}
\hline Parameters. & WT & NFR-3 & NFR-13 \\
\hline Half-saturation intensity $\left(\mu \mathrm{mol}\right.$ photons $\left.\mathrm{m}^{-2} \mathrm{~s}^{-1}\right)$ & $110 \pm 24^{\mathrm{a}}$ & $128 \pm 12^{\mathrm{a}}$ & $241 \pm 73^{\mathrm{b}}$ \\
\hline $\mathrm{P}_{\max }\left(\mu \mathrm{mol} \mathrm{O} \mathrm{mg} \mathrm{Chl}^{-1} \mathrm{~h}^{-1}\right)$ & $96 \pm 5^{\mathrm{a}}$ & $225 \pm 2^{\mathrm{b}}$ & $323 \pm 45^{\mathrm{c}}$ \\
\hline Respiration $\left(\mu \mathrm{mol} \mathrm{O}_{2} \mathrm{mg} \mathrm{Chl}^{-1} \mathrm{~h}^{-1}\right)$ & $25 \pm 3^{\mathrm{a}}$ & $52 \pm 7^{\mathrm{b}}$ & $73 \pm 6^{\mathrm{c}}$ \\
\hline Respiration $\left(\mathrm{fmol}\right.$ oxygen cell $\left.{ }^{-1} \mathrm{~h}^{-1}\right)$ & $6.4 \pm 0.8^{\mathrm{a}}$ & $5.7 \pm 0.7^{\mathrm{a}}$ & $5.1 \pm 0.4^{\mathrm{a}}$ \\
\hline $\mathrm{P}_{\max } /$ respiration (relative units) & $3.9 \pm 0.4^{\mathrm{a}}$ & $4.4 \pm 0.5^{\mathrm{b}}$ & $4.4 \pm 0.4^{\mathrm{b}}$ \\
\hline
\end{tabular}

\subsection{Phototolerance of WT and NFR Strains during EL Exposure}

EL conditions lead microalgae to photooxidation: the enhanced release of ${ }^{1} \mathrm{O}_{2}$ [44] results in lipid peroxidation, $\mathrm{Chl}$ bleaching and a consequent decline in the photosynthetic yield. Photoautotrophs have evolved a plethora of mechanisms aimed at limiting photodamage; these include the tight regulation of Car pool size, which is increased in response to the EL stress [45]. Therefore, the mutant strains NFR, due to a constitutive enhancement of Car content, are expected to counteract photooxidative conditions more efficiently, thus limiting photoinhibition. 
To characterize the photooxidative stress experienced by WT and NFR mutants, cells were transferred from control conditions to strong irradiance (Figure 2). A well-known consequence of ROS release in the thylakoids is the peroxidation of unsaturated lipids, a reaction that releases malondialdehyde (MDA) as a by-product. When cultures were exposed to $1400 \mu \mathrm{mol}$ photons $\mathrm{m}^{-2} \mathrm{~s}^{-1}$, at $24^{\circ} \mathrm{C}$ for $24 \mathrm{~h}$, rate of MDA release was $\sim 5$ times higher in WT cells with respect to NFR strains (Figure 2A), implying a significantly lower level of oxidative damage of the membranes in the mutants.
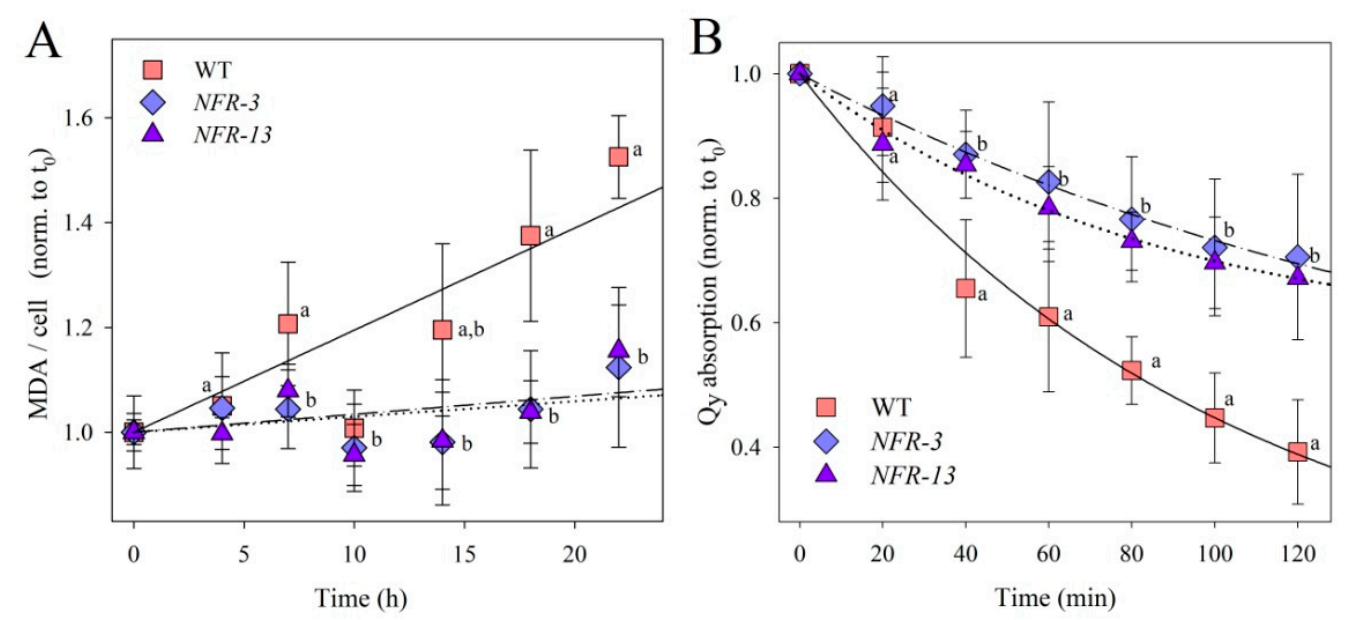

Figure 2. Photooxidation of C. vulgaris WT and NRF mutant genotypes under photooxidative stress. (A) Cell suspensions of WT and mutant strains were treated with $1400 \mu \mathrm{mol}$ photons $\mathrm{m}^{-2}$ $\mathrm{s}^{-1}$ at $20^{\circ} \mathrm{C}$, and kinetics of malondialdehyde (MDA) formation were followed. MDA is an index of membrane lipid peroxidation, and was quantified by HPLC as thiobarbituric reactive substances. Slopes of the linear fit (proportional to the rate of MDA release) were $0.0195 \pm 0.0056(\mathrm{WT})$, $0.0029 \pm 0.0024$ (NFR-3), $0.0034 \pm 0.0031$ (NFR-13). (B) Cell suspensions were treated with strong white light $\left(14,000 \mu \mathrm{mol}\right.$ photons $\left.\mathrm{m}^{-2} \mathrm{~s}^{-1}, 20^{\circ} \mathrm{C}\right)$ and the amount of $\mathrm{Chl}$ was evaluated by measuring the absorption area in the region $600-750 \mathrm{~nm}$. See Materials and Methods for details. Symbols and error bars show means $\pm \mathrm{SD}, n=4$. Values marked with the same letters are not significantly different from each other within the same time point (ANOVA followed by Tukey's post-hoc test at a significance level of $p<0.05)$.

We then analyzed cell suspensions of WT and mutant strains, by a time-course pigment bleaching upon transfer of cultures from low to extremely strong light $(14,000 \mu \mathrm{mol}$ photons $\mathrm{m}^{-2} \mathrm{~s}^{-1}$, at $20^{\circ} \mathrm{C}$ ). In all cultures, the total cell $\mathrm{Chl}$ content decreased progressively upon EL treatment (Figure 2B); however, the rate of Chl bleaching was twice faster in WT respect to NFR strains.

To further investigate the photooxidative stress experienced by these genotypes, liquid cultures were grown photoautotrophically under very high irradiance $(2500 \mu \mathrm{mol}$ photons $\mathrm{m}^{-2} \mathrm{~s}^{-1}, 24^{\circ} \mathrm{C}$ ), for 6 days in batch conditions. While the WT strain showed a long lag phase, NFR mutants exhibited a robust early growth phenotype, with NFR-13 culture displaying the faster growth rate (Figure S4). Among the mechanisms possibly underlying the higher biomass yield of NFR is the reduced optical density of culture, which allows for more homogeneous light distribution within the culture: indeed, pale-green mutants of different algal species [46-48] possess an enhanced photosynthetic productivity with respect to the corresponding WT strain. Therefore, the C. vulgaris mutant PG-14 previously described [36] was included in the growth trial as internal control. The PG-14 mutant showed a growth kinetic and final biomass yield higher than WT (Figure S4), consistent with previous report [36]. Growth enhancement of NFR strains with respect to WT was higher than with $P G-14$ under photooxidative conditions, thus suggesting higher productivity of NFR strains was caused not only by enhanced light diffusion in the culture, but also by higher tolerance to EL stress. 


\subsection{Biomass Productivity of WT and NFR Strains in Laboratory-Scale PBR}

The above results are consistent with a higher tolerance to photooxidative damage of NFR strains with respect to WT, which implies mutant strains could have an improved biomass productivity in PBR dense cultures under elevated irradiances. Therefore, strains were cultivated photoautotrophically over a period of 6 days in a laboratory-scale PBR, a semi-batch cultivation system consisting of $1 \mathrm{~L}$ glass cylinders. Cells were grown in minimal medium (BG-11), illuminated with $1400 \mu \mathrm{mol}$ photons $\mathrm{m}^{-2} \mathrm{~s}^{-1}$ at $24{ }^{\circ} \mathrm{C}$, under a day/night cycle of $16: 8 \mathrm{~h}$. Each cylinder was fed with a mix of air and $\mathrm{CO}_{2}$, whose relative abundance was tuned in order to maintain the $\mathrm{pH}$ of the medium between 6.8 and 7.2. Both NFR mutants showed a faster growth rate with respect to WT (Figure 3), and cell concentration at day 6 was about $5 \times 10^{8}$ cells mL $\mathrm{mL}^{-1}$ in both mutants vs. $3.6 \times 10^{8}$ cells $\mathrm{mL}^{-1}$ in the WT (Figure 3).

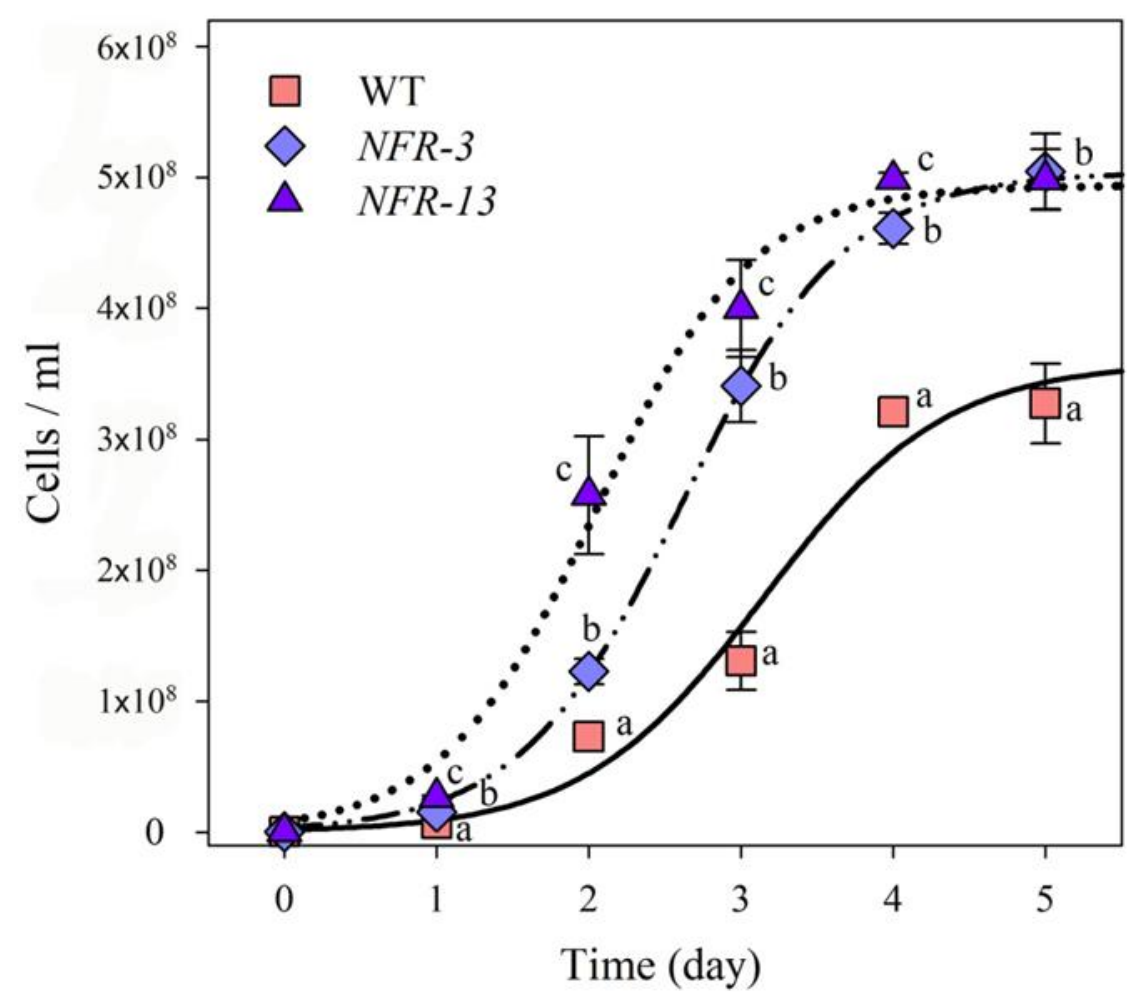

Figure 3. Growth curves of WT and mutant strains. Growth of WT and NRF mutant lines was performed under photoautotrophic conditions, in 1-L cylinders, illuminated with $1400 \mu \mathrm{mol}$ photons $\mathrm{m}^{-2} \mathrm{~s}^{-1}, 25^{\circ} \mathrm{C}$. Cultures were maintained in a semi-batch system fed with air $/ \mathrm{CO}_{2} \mathrm{mix} ; \mathrm{CO}_{2}$ supply was modulated in order to keep the $\mathrm{pH}$ of the medium always between 6.8 and 7.2. Symbols and error bars show means $\pm \mathrm{SD}, n=5$. Values marked with the same letters are not significantly different from each other within the same time point (ANOVA followed by Tukey's post-hoc test at a significance level of $p<0.05)$.

The specific growth rate $(\mu)$ for NFRs was higher than that obtained for the WT strain (Table 4). Furthermore, NFR mutant strains reached a biomass productivity of $0.56 \mathrm{~g} \mathrm{~L}^{-1}$ day $^{-1}$, which was significantly improved $(+23 \%)$ with respect to the yield obtained in WT $\left(0.43 \mathrm{~g} \mathrm{~L}^{-1}\right.$ day $^{-1}$, see Table 4$)$. 
Table 4. Growth parameters of WT and NFR strains, cultured in air $/ \mathrm{CO}_{2}$ bubbling system. Biomass content was measured by determination of dry biomass accumulated at the end of the cultivation period, divided by the number of days of cultivation. $\mu$, specific growth rate, was calculated from the slope of logarithmic cell concentration curve. Data are expressed as mean $\pm \mathrm{SD}, n=5$. Significantly different values (ANOVA followed by Tukey's post-hoc test at a significance level of $p<0.05$ ) are marked with different letters.

\begin{tabular}{ccc}
\hline Genotype & Mean Increase of Biomass $\left(\mathbf{g ~ L}^{-\mathbf{1}}\right.$ day $\left.^{-1}\right)$ & $\boldsymbol{\mu}\left(\right.$ day $\left.^{-1}\right)$ \\
\hline WT & $0.43 \pm 0.03^{\mathrm{a}}$ & $1.87 \pm 0.08^{\mathrm{a}}$ \\
\hline NFR-3 & $0.56 \pm 0.03^{\mathrm{b}}$ & $1.99 \pm 0.04^{\mathrm{b}}$ \\
\hline NFR-13 & $0.56 \pm 0.01^{\mathrm{b}}$ & $1.99 \pm 0.02^{\mathrm{b}}$ \\
\hline
\end{tabular}

The higher photoresistance of NFRs could be ascribed to a number of mechanisms, which include the photoprotective Non-Photochemical Quenching (NPQ). NPQ catalyzes the safe dissipation of the excitation energy in excess as heat, and its amplitude is modulate by the size of the xanthophyll pool $[49,50]$. Once assessed at steady-state photosynthesis, NPQ amplitude showed negligible differences between WT and NFR strains, over all the light intensities tested (Figure 4A and Figure S4). Alternatively, resistance and/or recovery from photoinhibitory EL treatment could be improved in mutant strains. To verify this possibility, we treated cells for $3 \mathrm{~h}$ at $1800 \mu \mathrm{mol}$ photons $\mathrm{m}^{-2} \mathrm{~s}^{-1}, 24{ }^{\circ} \mathrm{C}$, and measured $\mathrm{F}_{\mathrm{v}} / \mathrm{F}_{\mathrm{m}}$ ratio. The extent of PSII photoinhibition was significantly higher in WT vs. NFR strains, with $\mathrm{F}_{\mathrm{v}} / \mathrm{F}_{\mathrm{m}}$ values being $15 \%$ lower at the end of light treatment (Figure $4 \mathrm{~B}$ ); this is consistent with the milder oxidative damage experienced by the mutants (See Figure 2). However, recovery of $\mathrm{F}_{\mathrm{v}} / \mathrm{F}_{\mathrm{m}}$ in low light (Figure $4 \mathrm{~B}$, inset) showed that all genotypes performed equally, implying that the higher productivity of NFR strains was not due to a strengthened PSII repair system.
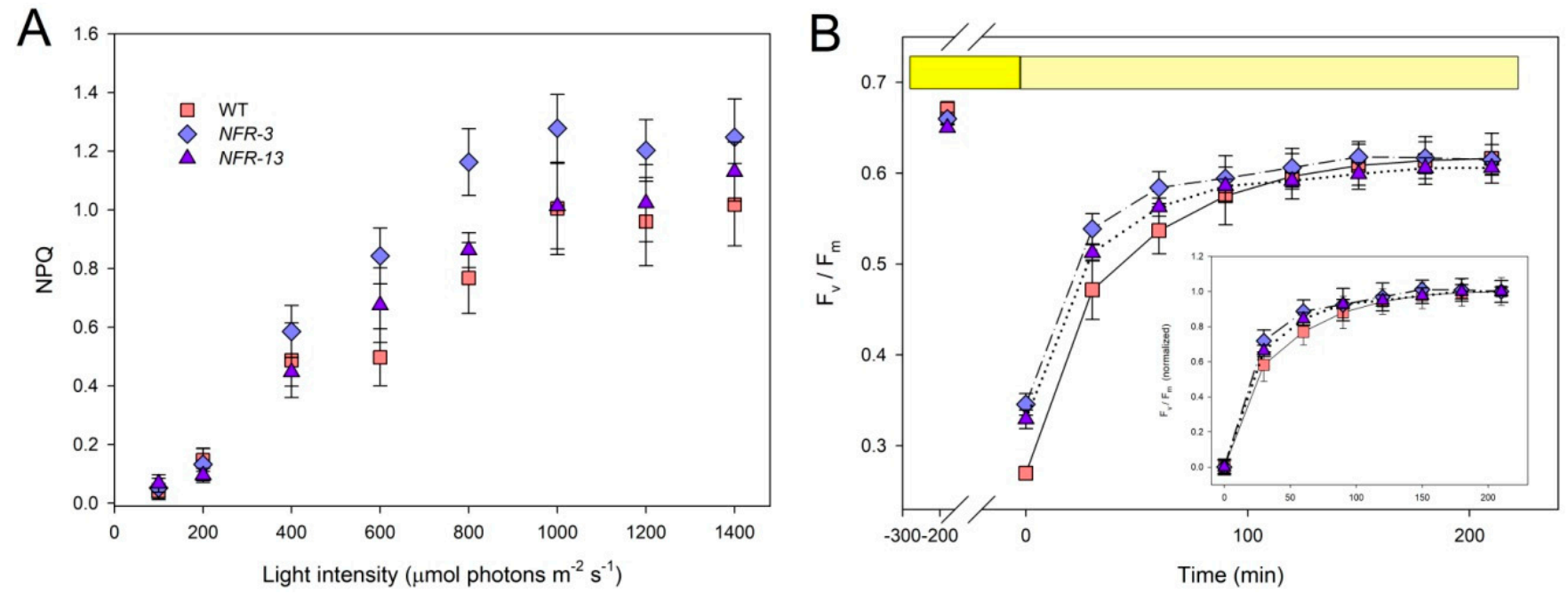

Figure 4. Analysis of Chl fluorescence during photosynthesis under EL. (A) Chl fluorescence was monitored in cultures dark-adapted for $2 \mathrm{~h}$. Cell suspensions were illuminated for $25 \mathrm{~min}$ and the non-photochemical quenching (NPQ) was determined at the end of light treatment (i.e., during steady-state photosynthesis). (B) PSII quantum yield recovery after EL treatment was quantified on WT and NFR strains by measuring $\mathrm{F}_{\mathrm{v}} / \mathrm{F}_{\mathrm{m}}$ recovery in low light $\left(20 \mu \mathrm{mol} \mathrm{photons} \mathrm{m}^{-2} \mathrm{~s}^{-1}\right.$, $24{ }^{\circ} \mathrm{C}$, light yellow bar) upon $3 \mathrm{~h}$ of EL treatment $\left(1800 \mu \mathrm{mol}\right.$ photons $\mathrm{m}^{-2} \mathrm{~s}^{-1}, 24^{\circ} \mathrm{C}$, yellow bar). (Inset) kinetics of $\mathrm{F}_{\mathrm{V}} / \mathrm{F}_{\mathrm{m}}$ were zeroed at the end of the EL treatment and normalized to the maximum $\mathrm{F}_{\mathrm{v}} / \mathrm{F}_{\mathrm{m}}$ during low light recovery. Data are expressed as mean $\pm \mathrm{SD}, n=4$. 


\subsection{Lipid Productivity under Nitrogen Starvation}

Microalgae gained increasing interest as a feedstock for biofuel production. Thus, an analysis of oil content in WT and mutant strains is crucial to assess their potential for commercial-scale oil production. EL [51] and nutrient deficiency [52] were recognized as stress factors which promote lipid accumulation in microalgae. Signaling involves photooxidative stress perception, while ROS and ROS-related by-products likely represent effector molecules, as suggested by the correlation between ROS level and lipid content in $C$. vulgaris cells [53]. It comes that the higher resistance to photooxidative damages, measured in NFR strains, might impair oil yield by affecting ROS-based crosstalk signals. Thus, the total lipid content was determined in WT and NFR strains. Microalgae were first grown in lab-scale PBR (see Figure 3) in nutrient-rich BG-11 medium, to attain high cell density, then were transferred to the same medium except that $\mathrm{N}$ was limiting $(-95 \% \mathrm{~N}$ content than standard BG-11). After 11 days of growth, lipid content per DW was determined gravimetrically (Table S1). Lipid content in WT algae was about $25 \%$ of the dry biomass, while cells from both NFR lines had a significantly lower lipid fraction, in the amount of $16 \%$ of the dry biomass.

\subsection{Genotypic Characterization of NFR Strains by Whole-Genome Sequencing}

The complex regulation of EL adaptation mechanisms is poorly understood in microalgae and most key factors are still awaiting elucidation. Mutant strains represent valuable tools to identify the underlying genotypic traits. Therefore, the two high Car content mutants, as well as the corresponding WT strain, were investigated in a whole-genome re-sequencing approach in order to identify the genetic background of the phototolerant phenotypes. For the systematic identification of the mutation(s) responsible for the Caraccumulating phenotypes, we applied a workflow based on open source bioinformatics tools. Sequencing the parental WT strain alongside NFR mutants enabled us to identify and remove common variants present in the WT background strain. Whole-genome sequencing was performed on an Illumina HiSeq platform. After trimming and quality filtering, the mean obtained coverage was 65.9X, 55.2X and 18.6X for the WT, NFR-3 and NFR-13 respectively. Percentage of the reads mapped to the reference genome were 99.4, 71.5, and $60.8 \%$ for WT, NFR-3, and NFR-13, respectively (Table 5).

Table 5. Summary of whole-genome sequencing and read mapping for WT and two EMS-treated mutants.

\begin{tabular}{ccccc}
\hline Sample & $\begin{array}{c}\text { Total Number of } \\
\text { Reads Produced }\end{array}$ & $\begin{array}{c}\text { Total Number of } \\
\text { Reads after Trimming }\end{array}$ & Mapped Reads & Mean Fold Coverage \\
\hline WT & $38,406,276$ & $25,308,558$ & $25,157,713$ & $65.9 \times$ \\
\hline NFR-3 & $37,378,884$ & $28,743,282$ & $20,555,916$ & $55.2 \times$ \\
\hline NFR-13 & $17,628,716$ & $11,931,178$ & $7,249,676$ & $18.6 \times$ \\
\hline
\end{tabular}

After the filtering process and manual inspection with Integrated Genomics Viewer (IGV), we detected a total of 34 variations (SNPs and small INDELs, see also Figure S5) that differed between the mutants and parental WT. Variants are listed in Table 6, and discussed further ahead. 


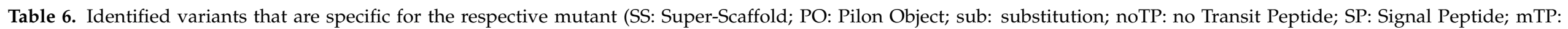
mitochondrial Transit Peptide; cTP: chloroplast Transit Peptide; * indicates low confidence for SIFT algorithm prediction—see Materials and Methods for details).

\begin{tabular}{|c|c|c|c|c|c|c|c|c|}
\hline \multirow{2}{*}{$\begin{array}{l}\text { Mutant } \\
\text { NFR-13 }\end{array}$} & \multirow{2}{*}{$\begin{array}{c}\text { Variant pos. } \\
\text { SS_1:3929152 }\end{array}$} & \multicolumn{2}{|c|}{ Ref/Alt } & \multirow{2}{*}{$\begin{array}{c}\text { Region } \\
\text { Exon }\end{array}$} & \multirow{2}{*}{$\begin{array}{c}\text { CDS Effect [SIFT Prediction] } \\
\text { Missense sub. (Arg598Gln) [SIFT: Tolerated] }\end{array}$} & \multirow{2}{*}{$\begin{array}{c}\text { TargetP } \\
\text { noTP }\end{array}$} & \multirow{2}{*}{$\begin{array}{c}\text { ChloroP } \\
-\end{array}$} & \multirow{2}{*}{$\begin{array}{c}\text { Putative Gene Function (Gene ID) } \\
\text { Predicted protein (g380) }\end{array}$} \\
\hline & & G & $\mathrm{A}$ & & & & & \\
\hline NFR-13 & SS_2:14375 & G & A & Exon & Missense sub. (Arg150Cys) [SIFT: Deleterious] & noTP & - & $\begin{array}{l}\text { RNA helicase, activating signal cointegrator } 1 \\
\qquad(\mathrm{~g} 5804)\end{array}$ \\
\hline NFR-13/NFR-3 & SS_2:5043375 & G & $\mathrm{C}$ & Exon & Missense sub. (Gln67His) [SIFT: Tolerated] & noTP & - & Predicted protein (g2438) \\
\hline NFR-13 & SS_3:393571 & G & A & Exon & Missense sub. (Arg470Cys) [SIFT: Deleterious *] & noTP & - & $\begin{array}{l}\text { Serine/threonine-protein phosphatase 2A } 65 \mathrm{kDa} \\
\text { regulatory subunit A beta isoform-like (g2544) }\end{array}$ \\
\hline NFR-13/NFR-3 & SS_5:2569375 & G & $\mathrm{C}$ & Exon & Missense sub. (Glu178Asp) [SIFT: Deleterious] & noTP & cTP & Glycerol-3-phosphate acyltransferase 3 (g4271) \\
\hline NFR-13 & SS_5:2624939 & $\mathrm{C}$ & $\mathrm{T}$ & Exon & Missense sub. (Ser119Leu) [SIFT: Deleterious] & SP & - & Serine threonine- kinase receptor R831 (g4284) \\
\hline$N F R-3$ & SS_10:492953 & G & A & Exon & Missense sub. (Arg233Cys) [SIFT: Deleterious] & noTP & - & S49 family peptidase (g6424) \\
\hline NFR-13 & SS_13:1005023 & G & A & Exon & Missense sub. (Ala80Thr) [SIFT: Tolerated] & $\mathrm{mTP}$ & cTP & Acylamino-acid-releasing enzyme-like (g7937) \\
\hline NFR-3 & SS_14:552899 & G & $\mathrm{A}$ & Exon & Missense sub. (Gly391Asp) [SIFT: Deleterious] & noTP & - & Biosynthetic arginine decarboxylase (g9015) \\
\hline NFR-13 & SS_14:1569725 & $\mathrm{C}$ & $\mathrm{T}$ & Exon & Missense sub. (Ala6Thr) [SIFT: Deleterious *] & notP & - & Hypothetical protein (g8357) \\
\hline NFR-13/NFR-3 & SS_18:1233529 & G & $\mathrm{A}$ & Exon & Missense sub. (Gly1235Arg) [SIFT: Deleterious *] & notP & - & Hypothetical protein (g9528) \\
\hline NFR-13/NFR-3 & SS_2:4256144 & $\mathrm{C}$ & $\mathrm{T}$ & Exon & Synonymous sub. & noTP & - & haloalkane dehalogenase (g2220) \\
\hline NFR-13/NFR-3 & SS_2:4392343 & $\mathrm{C}$ & G & Exon & Synonymous sub. & noTP & - & solute carrier family 25 member 44 (g2251) \\
\hline NFR-13/NFR-3 & SS_5:1173035 & G & $\mathrm{A}$ & Exon & Synonymous sub. & noTP & - & Large subunit GTPase 1 (g3878) \\
\hline NFR-13/NFR-3 & PO_26F:57866 & $\mathrm{C}$ & $\mathrm{T}$ & Exon & Synonymous sub. & noTP & - & Predicted protein (g10631) \\
\hline NFR-3 & SS_1:3944123 & $\mathrm{C}$ & $\mathrm{T}$ & Intron & No & $\mathrm{mTP}$ & cTP & Methionyl-tRNA synthetase (g376) \\
\hline NFR-13/NFR-3 & SS_1:5342472 & G & $\mathrm{A}$ & Intron & No & noTP & cTP & $\begin{array}{c}\text { Cleavage and polyadenylation specificity factor } \\
\text { subunit } 1 \text { (g15) }\end{array}$ \\
\hline NFR-13/NFR-3 & SS_2:4545066 & G & A & Intron & No & notP & - & Putative Xaa-Pro aminopeptidase 3 (g2293) \\
\hline NFR-13/NFR-3 & SS_2:4545075 & G & A & Intron & No & noTP & - & Putative Xaa-Pro aminopeptidase 3 (g2293) \\
\hline NFR-13/NFR-3 & SS_3:1002678 & A & G & Intron & No & $\mathrm{SP}$ & - & Hypothetical protein (g2664) \\
\hline
\end{tabular}


Table 6. Cont

\begin{tabular}{|c|c|c|c|c|c|c|c|c|}
\hline Mutant & Variant pos. & \multicolumn{2}{|c|}{ Ref/Alt } & Region & CDS Effect [SIFT Prediction] & TargetP & ChloroP & Putative Gene Function (Gene ID) \\
\hline NFR-13/NFR-3 & SS_5: 1971361 & $\mathrm{AG}$ & $\mathrm{A}$ & Intron & No & noTP & - & $\begin{array}{l}\text { MAU2 chromatid cohesion factor-like protein } \\
\text { (g4126) }\end{array}$ \\
\hline NFR-3 & SS_5:2687539 & G & $\mathrm{C}$ & Intron & No & notP & cTP & Serine/threonine-protein kinase sepA (g4294) \\
\hline NFR-13/NFR-3 & SS_6: 1727681 & $\mathrm{TC}$ & $\mathrm{T}$ & Intron & No & cTP & cTP & Water chloroplastic-like (g4763) \\
\hline NFR-13/NFR-3 & SS_13:303225 & G & $\mathrm{A}$ & Intron & No & notP & cTP & Allophanate hydrolase (g7748) \\
\hline NFR-3 & SS_13:1920503 & G & A & Intron & No & notP & - & $\begin{array}{l}\text { U3 small nucleolar ribonucleoprotein protein IMP4 } \\
\qquad(\mathrm{g} 8749)\end{array}$ \\
\hline NFR-3 & SS_7:737237 & G & $\mathrm{C}$ & Intron & No & notP & - & Sodium:proline symporter (g5015) \\
\hline NFR-3 & SS_8:332225 & $\mathrm{C}$ & $\mathrm{T}$ & Intron & No & notP & cTP & MFS general substrate transporter (g5411) \\
\hline NFR-13 & SS_1:269018 & $\mathrm{C}$ & A & $\begin{array}{l}\text { Splice } \\
\text { region }\end{array}$ & No & noTP & - & Preprotein translocase subunit SecA (g1481) \\
\hline NFR-13/NFR-3 & SS_3:344676 & G & A & $\begin{array}{l}\text { Splice } \\
\text { donor }\end{array}$ & Yes & notP & - & $\begin{array}{c}\text { E3 Ubiquitin-protein Ligase SP1 related } \\
\text { [PTHR47568:SF2] (g2532) }\end{array}$ \\
\hline NFR-13/NFR-3 & SS_13:2646657 & G & A & $\begin{array}{l}\text { Splice } \\
\text { region }\end{array}$ & No & cTP & cTP & S1 motif domain-containing protein (g8549) \\
\hline NFR-13 & SS_1:2991332 & G & $\mathrm{T}$ & Intergenic & No & notP & - & $\begin{array}{c}\text { Upstream of: Nuclear/nucleolar GTPase } 2 \text { (g672); } \\
\text { Nuclear transport receptor (g671) }\end{array}$ \\
\hline NFR-13/NFR-3 & SS_5:1304829 & $\mathrm{C}$ & $\mathrm{T}$ & Intergenic & No & notP & - & $\begin{array}{l}\text { Upstream of predicted protein ( g3913). } \\
\text { Downstream of predicted protein (g3914) }\end{array}$ \\
\hline$N F R-3$ & SS1:3529923 & A & AT & Intergenic & No & notP & - & $\begin{array}{c}\text { Downstream of transcription initiation factor IIB-2 } \\
\text { (g501). Downstream of putative phosphatase 2C } 35 \\
\text { (g500) }\end{array}$ \\
\hline
\end{tabular}




\section{Discussion}

Realization of microalgae potential to satisfy global demands requires a decrease of the current production costs for biomass. Among factors contributing to the price of bio-products purified from microalgae are energy and material inputs, as well as cellular content of the desired molecule [54]. It comes that cost-effective production needs selection of strains with enhanced accumulation of a valuable compound. Moreover, productivity of the most common industrial strains is far lower than maximal theoretical estimations, suggesting that removing bottlenecks which limit biomass yield is crucial in strategies aiming to make algal biofactories profitable on an industrial scale.

\subsection{Optimization of Light-Use Efficiency Enhances Biomass Yield}

The inefficient use of light, due to high optical density of cultures, is among the factors which limit algal biomass production in the artificial conditions of a PBR. Indeed, it was shown that the biomass yield in PBRs increased with decreasing the light path, which allows for more homogeneous light distribution in the culture vessel [55]. Unfortunately, short light paths in flat-panel PBR limit the overall volume of culture and, thus, the economic viability of large-scale plants.

A number of studies have shown that biomass yield can be improved by optimizing optical features of algal cultures through genetic engineering approaches: targeting genes such as TLA1, which control antenna size in Chlamydomonas reinhardtii, resulted in higher biomass yield [56]; random mutagenesis applied to species with a high industrial interest such as C. sorokiniana and N. gaditana, selected pale-green mutants which exhibited increased light-use efficiency [47,48]. A similar approach was used in this work with Chlorella vulgaris, searching for low optical density traits to increase light penetration and light-to-biomass yield, in order to find out a background strain for further domestication projects.

Both NFR mutants are defective in PSII antenna size, consisting of a LHCII content of $31 \%$ (in NFR-3) and 32\% (in NFR-13) with respect to WT (Figure 1B). Fluorescence induction in cells treated with DCMU confirmed that both NFR strains had a reduced PSII functional antenna size (Figure 1A).

Photosynthetic rate was significantly enhanced in both NFR strains; yet this effect was larger in the strain with lower cross-section (Table 3): indeed, the $P_{\max }$ of NFR-3 was $134 \%$ larger than in WT at saturating irradiances, while that of NFR-13 increased by $236 \%$, implying the reduction in antenna size enhanced photosynthetic yield. These results are consistent with those reported for $C$. reinhardtii tla1 and tla3 strains with truncated antenna system $[46,56]$.

Photooxidative stress caused by EL conditions is a major reason for yield reduction in algal cultures [57]. Microalgae exposed to saturating light intensity undergo PSII damage, which must be repaired by de novo synthesis [58]. The process impairs the overall efficiency of light-to-biomass conversion efficiency, therefore, it should be minimized to achieve high productivity.

Moreover, cells in dense suspensions are rapidly mixed and experience a rapid shift from darkness to saturating light, and mixing rate on a ms time-scale can easily be achieved in tubular PBR [59]. The consequent fluctuations in light intensity are faster than mechanisms required for counteracting EL stress, such as the activation of dissipative channels or the reversible phosphorylation of LHCII. Therefore, the repeating fluctuations between low and high light phases challenge the light acclimation capacity of the photosynthetic apparatus [60]. In this work, growth rates of cultures were measured in the long term under strong irradiance $\left(2500 \mu \mathrm{mol}\right.$ photons $\left.\mathrm{m}^{-2} \mathrm{~s}^{-1}\right)$ in batch conditions (Figure S4). During 6 days of growth, the PG-14 strain we used as a reference with reduced antenna size and without Car content enhancement [36] showed a 57\% increase in productivity with respect to WT (see Figure S3B), meaning that a reduction of LHC per PSII by $40 \%$ (previously determined for this genotype) significantly improved the phototolerance of $C$. vulgaris cells. Interestingly, NFR mutations showed a further increased growth rate with respect to both WT and PG-14 under EL. We conclude that overaccumulation of Car and 
diminished optical density of the cultures have a synergistic effect in improving light-use efficiency under strong irradiance.

As a consequence of the highly reactive excited states generated during oxygenic photosynthesis, algae have evolved a number of photoprotective mechanisms to limit damage to cell structures [61]. These mechanisms are effective in (i) regulating either ${ }^{1} \mathrm{Ch}^{*}$ [22] or ${ }^{3} \mathrm{Chl}^{*}$ state formation [35], thus, ROS release, or (ii) scavenging ROS [62]. The first group includes the energy dissipation events which diminish the excitation pressure on PSII, while the antioxidant network comprises scavenging enzymes and antioxidant molecules [63], including the thylakoid-bound antioxidants Car which catalyze both quenching of ${ }^{1} \mathrm{Chl}{ }^{*}$ and ${ }^{3} \mathrm{Chl}{ }^{*}$ and scavenging of ${ }^{1} \mathrm{O}_{2}$.

NPQ is the main mechanism that regulates ${ }^{1} \mathrm{Chl}^{*}$ lifetime [64,65], making it a candidate process underlying higher biomass yield of NFR strains. However, NPQ amplitude, once measured over a range of irradiances, was essentially the same in WT and NFR genotypes (Figure 4A), implying that differences in growth cannot be ascribed to changes in Chl quenching activity. A similar consideration applies to the activity of PSII repair (Figure 4B).

The phototolerance of NFR mutants was significantly higher vs. WT. The observed lower lipid peroxidation and higher resistance to $\mathrm{Chl}$ photobleaching (Figure 2) suggest either a reduced ROS release or a more efficient scavenging activity of ROS in the chloroplasts. The latter appears as the most likely hypothesis, as the content in the Car antioxidants is far higher in NFR strains (Table 1). Indeed, mutants impaired in the accumulation of Cars, in both plants and algae, were unable to acclimate to high irradiance, and progressively lost photosynthetic capacity along with oxidation of pigment-protein complexes and accumulation of ROS [66,67].

In addition to enhanced antioxidant capacity, other mechanisms could improve lightto-biomass conversion efficiency in NFR strains. We expect a lower ROS release in mutant lines due to higher antioxidant capacity. Depending on its concentration, ${ }^{1} \mathrm{O}_{2}$ was shown to play a role as second messenger in cell signal transduction pathways, controlling a number of stress-response mechanisms [68]; e.g., in C. reinhardtii, specific promoter regions mediate transcriptional responses to ${ }^{1} \mathrm{O}_{2}[69,70]$, while experience of a moderated ${ }^{1} \mathrm{O}_{2}$ level was shown to improve resistance of algal cells to harsher photooxidative stress [68].

A number of plastid-derived signals were shown to be involved in the adaptation of cells to the light environment, including cleavage products of Car or intermediates of Car biosynthesis [71]. Indeed, under EL stress, oxidized by-products of $\beta$-carotene, such as $\beta$-cyclocitral $(\beta-C C)$ and $\beta$-ionone, work as signaling molecules in plants, enhancing resistance to EL and other stresses [72,73]. Release of Car cleavage products was also described in cyanobacteria [74], thus suggesting these signal pathways are ubiquitous in the green lineage.

Interestingly, previous work showed that resistance to oxidative stress can also be obtained without any increase in Car/Chl ratio; this is the case of ${ }^{1} \mathrm{O}_{2}$-resistant (SOR) strains [36], the photoprotection capacity of which was significantly enhanced than WT strain, despite the pool of Car not being differentially affected in these genotypes upon light stress. However, SOR strains, when cultivated in the same lab-scale PBR here reported, at $1400 \mu \mathrm{mol}$ photons $\mathrm{m}^{-2} \mathrm{~s}^{-1}$, stood out for higher mean biomass productivity than both NFR strains. These $C$. vulgaris genotypes can be ranked with respect to the light-to-biomass conversion efficiency as follows: WT $<$ NFRs $<$ SOR $-5=$ SOR-6 [36].

In the condition of prolonged EL treatment of cultures tested here, our results point to a specific involvement of Car in the defense of the photosynthetic machinery against photooxidative damage. Data also imply that multiple mechanisms take part in photoprotecting algal cells: indeed, the EL resistance measured in SOR strains was not related to any increase in the size of the Car pool.

\subsection{Influence of ROS-Resistance Traits on Stress-Induced Lipid Production}

While sustained ROS release under EL causes lipid peroxidation, mild photooxidative stress conditions enhance lipid accumulation in oleaginous microalgae [75]. The mecha- 
nism possibly underlying such response is a ROS signaling network that up-regulates the pathway of fatty acid biosynthesis [76]. Consistently, in C. vulgaris, a positive correlation between oil content and ROS level was found [53], while in S. cerevisiae the endoplasmic reticulum triggers development of lipid bodies upon perception of oxidative stress [77]. Overall, evidence for a correlation between intracellular ROS level and abundance of TAGs is still limited and molecular details are missing. In the case of NFR strains, if ROS level promotes fatty acid biosynthesis by complex signaling pathways, then we might expect an inhibiting effect in the accumulation of oil due to the enhanced antioxidant activity of the mutants. Indeed, quantification of intracellular lipid content, upon short-term nitrogenstarvation treatment of cultures, supports this hypothesis: oil content was significantly reduced in both NFR strains ( $-35 \%$ vs. WT, see Table S1). Alternatively, such a change in lipid content could be a consequence of the missense amino acid substitution in Glycerol-3phosphate acyltransferase 3 (Table 6, Figure S7), which is indeed involved in the terminal steps of triacylglycerol biosynthesis in the endoplasmic reticulum (see below).

\subsection{NFR as Promising Car Producer Strains for Commercial Applications}

The demand for nutraceuticals has been increasing over the last years. Microalgae contribute as being rich in proteins and bioactive compounds such as essential fatty acids, Car and vitamins. However, only a few microalgal species are currently commercialized as nutraceuticals [7]. Chlorella vulgaris is among the few species approved by the European Food Safety Authority for human consumption. Chlorella biomass is widely used as food supplement or to enhance the nutritional value of food products [78]. However, organoleptic features of algal biomass, e.g., strong green color or grassy taste, might disappoint the consumer, preventing them from including supplemented food in their diet [79]. Isolation of mutant strains with altered pigmentation, e.g., higher Car/Chl ratio, does represent an alternative strategy for improving the qualities of algal biomass as food additive. Furthermore, forward genetic approach is of particular relevance in the food industry, since it avoids restrictions to GMO [80].

In this work we developed two Chl-deficient strains of Chlorella vulgaris of interest for nutritional applications. The changes in color of NFR-3 and NFR-13 mutant strains in $\mathrm{N}$-limited conditions (Figure S1) are due to a lower Chl content, and to a $70 \%$ and $146 \%$ increase in Car content, respectively, with respect to the standard BG-11 medium. Under photoautotrophic growth, both strains showed a significantly improved growth performance with respect to WT, reaching a concentration of $3.79 \mathrm{~g} \mathrm{FW} \mathrm{L}^{-1}$ (NFR-3) and $4.74 \mathrm{~g} \mathrm{FW} \mathrm{L}^{-1}$ (NFR-13) in batch conditions. Moreover, the improved growth rates were maintained even when scaled up in 1-L lab-scale PBR (Figure 3, Table 4), a result which support their feasibility as potential candidates for the food industry and for the development of novel food supplements.

The strains here described point to $C$. vulgaris as an attractive candidate for the production of xanthophylls: NFR-13 strain showed a volumetric lutein content of $40 \mathrm{mg} \mathrm{L}^{-1}$ under N-starvation, significantly higher than those reported for other lutein-producing strains grown under photoautotrophic conditions [45,81]. Moreover, NFR-13 cultures showed a high specific growth rate $\left(0.08 \mathrm{~h}^{-1}\right)$, thus, it represents a promising strain for the production of xanthophylls for commercial applications.

\subsection{Whole-Genome Sequencing to Identify Gene(s) Responsible for the Enhanced Light-Use Efficiency in C. vulgaris}

The phenotype of NFR strains is the product of one or more mutations which affect regulatory and metabolic processes of Car biosynthesis. Here, we identified genetic variants among which these mutations can be searched for, and suggest how these variations could alter gene function, yielding the observed phenotype of NFR-3 and NFR-13 mutants.

1. Glycerol-3-phosphate acyltransferase 3. A transversion (G to $C$ ) was observed at nucleotide 534 on the 6 th exon. This results in missense amino acid substitution of a glutamic acid into an aspartic acid, a mutation shared by both NFR mutants, affecting 
a subunit involved in neutral lipid metabolism. Glutamic acid and aspartic acid are both acidic amino acids with side chains containing a carboxylic acid group which carries a full negative charge. In terms of interaction modes, both amino acids include ionic, van der Waals and H-bonds. However, glutamic acid differs from aspartic acid only in that its side chain is longer by one methylene group. This results in higher side chain flexibility in glutamic acid compared to aspartic acid whose side chain flexibility is moderate. Transmembrane topology prediction indicates that the site of mutation is at the boundary between cytoplasmic domain (residues 169-179) and the consecutive transmembrane region (residues 180-199). Multiple sequence alignments of top BLAST hits indicate that the last two residues of the cytoplasmic domain (E178 and R179) are conserved among green cut species (Figure S7). Glycerol3-phosphate acyltransferase 3 is a key component of the diglyceride-3-phosphate synthesis pathway. Consistently, its activity has been reported to be directly correlated to the amount of glycerophospholipids in E. coli cells [82] and used as a target for membrane engineering to enhance production and accumulation of $B$-carotene [83].

2. E3 Ubiquitin-protein Ligase SP1-related (PTHR47568:SF2) encoding sequence contains a splice donor variant and is shared by both mutants, NFR-3 and NFR-13. A transition (G to A) occurs at the first nucleotide of the second intron affecting canonical GT-AG splice site pairs. Group of E3 ubiquitin-protein ligases, including SP1 from Arabidopsis (UniProtKB: Q8L7N4), are involved in regulation of plastid's proteome via ubiquitination and subsequent degradation of translocon at the outer envelope membrane of chloroplasts (TOC) complexes [84]. In addition, it promotes stress tolerance by depleting the chloroplast protein import apparatus, which limits photosystem assembly and the potential for ROS formation [85]. Formighieri et al. [86] demonstrated that absence of ARSA1, a protein localized in the C. reinhardtii cytosol, led to a strongly decreased Chl content per cell; ARSA1 was shown to be required for optimal biogenesis of photosystems due to its involvement in the accumulation of TOC 34 , a component of the outer chloroplast membrane translocon complex. Interestingly, in both species, a mutation targeting a component interacting with TOC is associated with a pale green phenotype.

3. Serine/threonine-protein phosphatase $2 \mathrm{~A} 65 \mathrm{kDa}$ regulatory subunit $\mathrm{A}$ contains variation observed in NFR-13 mutant only. Transition mutation (C to T) results in substitution of an arginine by cysteine. 2A protein phosphatases are evolutionarily conserved and carry out multiple functions such as growth- and stress-related signaling, cell cycle regulation, vesicle trafficking, as well as regulation of the activities of a number of enzymes involved in key metabolic pathways [87]. The mutant 2A protein phosphatase in NFR-13 contains fatty acid desaturase domain (IPR005804) which is involved in the lipid metabolic process (GO:0006629).

4. Both NFR-3 and NFR-13 share an intronic variation on Allophanate hydrolase (g7748). In Chlamydomonas reinhardtii, allophanate hydrolase is involved in urea hydrolysis to produce ammonium depending on the source of nitrogen available [88].

5. Another exonic mutation found only in NFR-3 targets biosynthetic arginine decarboxylase (g9015) involved in the polyamine biosynthesis pathway. In plants, polyamine accumulation was shown to correlate with Car content [89].

6. A missense amino acid substitution (Arg233Cys) was identified on S49 family peptidase (g6424) in NFR-3. The predicted protein contains peptidase_S49 domain (IPR002142) from residues 20-236. InterPro entry (IPR002142) describes proteolytic enzymes that exploit serine in their catalytic activity. The sequences of these ubiquitous enzymes are variously annotated in different taxonomic groups. In plants, these proteolytic sequences are annotated as Signal peptide peptidase A (SppA; protease IV; MEROPS identifier S49.001) which are involved in cleavage of signal peptides.

7. NFR-13 mutant contains a point mutation resulting in Ala80Thr on Acylamino-acidreleasing enzyme-like (g7937). Acylamino-acid-releasing enzymes have been identified and characterized in plants. They are found to be mainly localized in the stroma 
of chloroplasts, and are possibly involved in degradation of glycated/oxidized proteins, such as glycated RuBisCO (ribulose-1,5-bisphosphate carboxylase/oxygenase), and thus contribute to sustain the chloroplast antioxidative system [90].

Lastly, 6 out of 34 identified variants lie within or in close proximity to gene bodies containing transcriptional or translational regulatory domains, namely, transcription initiation factor IIB-2 (g501, NFR-3), Nuclear/nucleolar GTPase 2 (g672, NFR-13), Nuclear transport receptor (g671, NFR-13), S1 motif domain-containing protein (g8549, NFR-3/NFR-13), U3 small nucleolar ribonucleoprotein protein IMP4 (g8749, NFR-3). In NFR-13, an amino acid substitution (Arg150Cys) on an RNA helicase (g5804) with U5 small nuclear ribonucleoprotein $200 \mathrm{kDa}$ helicase domain (PTHR24075:SF5) is identified. This predicted protein is likely to be involved in spliceosome assembly, activation and disassembly (inferred from sequence similarity to UniProtKB:P32639).

\section{Conclusions}

Here we show that $C$. vulgaris mutagenesis and selection in the Car biosynthesis inhibitor norflurazon resulted in a significant increase in the size of the Car cellular pool. The mutant strains were more tolerant to EL conditions, as shown by reduced lipid peroxidation and pigment bleaching. Stress protection is probably due to the function of Car in preventing oxidative damage of membranes. Moreover, these strains showed an improved biomass productivity with respect to WT in mass cultures under EL conditions. Overall, our results show that a domestication strategy, focused on the modulation of both cell optical density and resistance to photooxidative stress, succeeded in the development of improved strains, which is of interest for industrial production. Although our genomic analysis cannot unequivocally identify the genetic origin of the phenotypes reported for NFR genotypes, we can tentatively propose that the mutation on Glycerol-3-phosphate acyltransferase 3, which is shared by NFR-13 and NFR-3 mutants, might be involved in the reduced accumulation of lipids upon N starvation (Table S1). Similarly, the mutation at the E3 Ubiquitin-protein Ligase SP1 might cause the pale green phenotype through its effect on TOC complex assembly. Experimental verification of these hypotheses will involve targeting these individual genes by either genome editing [91] or tapping from the mutant collection [92] in the green algae relative species Chlamydomonas reinhardtii.

\section{Materials and Methods}

Strains and culture conditions. Chlorella vulgaris WT strain was obtained from the SAG Culture Collection of Algae (Goettingen University, Germany, http://www.unigoettingen.de/en/catalogue-of-strains/185049.html (accessed on 1 May 2021)) as SAG strain number 211-11p. Cells were maintained on TAP agar plates [93] and grown in either minimal (BG-11) [94] or rich (TAP) liquid media. Shaken flasks (120 rpm) and plates were illuminated from the top with $70 \mu \mathrm{mol}$ photons $\mathrm{m}^{-2} \mathrm{~s}^{-1}$, photoperiod of $16 / 8 \mathrm{~h} \mathrm{light} /$ dark, $25^{\circ} \mathrm{C}$ (control condition); irradiance was provided by warm-white LEDs (Epistar 35mil Chip High Power LED, warm white LEDE-P20B-DW, Wayjun Tech., Shenzhen, China). For nitrogen starvation experiments, cells were grown in the BG-11 medium containing excess nitrogen source $\left(\mathrm{NaNO}_{3} 17 \mathrm{mM}\right)$; they were then collected by centrifugation at the end of the logarithmic growth phase, washed twice with sterile water, and re-suspended in a modified BG-11 medium with limiting $\mathrm{N}$ source $\left(\mathrm{NaNO}_{3} 0.8 \mathrm{mM}\right)$. For physiological measurements, cultures were harvested during the logarithmic growth phase (about 1-3 $\times 10^{7}$ cells $\mathrm{mL}^{-1}$ ).

Mutagenesis and screening protocols. Liquid cultures of $C$. vulgaris WT strain were harvested by centrifugation at the exponential phase of growth $\left(\sim 1 \times 10^{6}\right.$ cells mL $\left.{ }^{-1}\right)$, re-suspended in fresh BG-11 medium to $5 \times 10^{7}$ cells mL ${ }^{-1}$, and treated with $2.2 \%(w / v)$ of ethyl methanesulfonate (EMS). The survival curve for mutagenesis with EMS was carried out to determine the mutagen concentration which resulted in around $5-10 \%$ of cell viability. Upon $2 \mathrm{~h}$ maintenance in the dark, to prevent light-activated DNA repair, cells were plated at 100-fold dilution on minimal medium, and the inhibitor norflurazon (NF) was used 
as selection method. NF is a herbicide inhibiting the carotenogenic enzymes phytoene desaturase [39]. A wide range of concentrations of the chemicals were previously tested to find out the minimal concentration which inhibited grown of the WT strain. For the selection of NFR (norflurazon resistant) strains, mutagenized cells were spread on a solid minimal medium containing $4 \mu \mathrm{M} \mathrm{NF}$ and incubated at $70 \mu \mathrm{mol}$ photons $\mathrm{m}^{-2} \mathrm{~s}^{-1}$ for 2 weeks; single colonies appeared after 14 days.

Cells were subjected to two rounds of random chemical mutagenesis with EMS. In a first selection step, lines were selected for pale green phenotype by direct sight inspection, then pale green strains were pooled, grown to enhance cell number, submitted to a second treatment with EMS, and mutants were selected for resistance to inhibition of Car biosynthesis.

Selected lines upon two rounds of mutagenesis were inoculated onto fresh minimal medium, grown in the light for seven days, and the Chl content per cell was determined. The herbicide-resistant colonies were sub-cultivated several times in liquid BG-11 medium containing $4 \mu \mathrm{M}$ NF to check their resistance to the herbicide and further analyzed for Car and $\mathrm{Chl}$ content per cell and for growth rate.

Cell count and pigment analysis. Cell density was measured using an improved Neubauer hemocytometer. Pigments were extracted from intact cells with 100\% dimethyl-formamide (DMFA). The supernatant of each sample was recovered after centrifugation (10 $\mathrm{min}$ at $15,000 \times g, 4{ }^{\circ} \mathrm{C}$ ), and pigments were separated and quantified by HPLC [95].

Gel Electrophoresis and Immunoblotting. For SDS-PAGE and immunotitration analysis, cells were resuspended in Loading Buffer (5\% glycerol, 1\% SDS, 2.5\% 2-mercaptoethanol, $0.1 \mathrm{M}$ Tris, $0.1 \mathrm{M}$ Tricine $\mathrm{pH}$ 8.45) and ground in a tissue homogenizer (Precellys, Bertin, France) by adding a ceramic lysing matrix. The supernatant of each sample was recovered after centrifugation $\left(10 \mathrm{~min}\right.$ at $\left.15,000 \times \mathrm{g}, 4^{\circ} \mathrm{C}\right)$ and $\mathrm{Chl}$ content of extracts was determined by fitting of the spectra of acetone extracts with the spectra of individual pigments [96]. SDS-PAGE analysis was performed with the Tris-Tricine buffer system [97]. For immunotitration [98], a range of total protein extract corresponding to $0.25-1.0 \mu \mathrm{g}$ of Chl were loaded for each sample and electroblotted on nitrocellulose membranes (Amersham Protran ${ }^{\circledR}$, pore size $0.45 \mu \mathrm{m}$ ). Proteins were detected with primary antibodies (home-made, $\alpha$-CP43 and $\alpha$-LHCII; from Agrisera, $\alpha$-PsaA AS06-172-100) and an alkaline phosphatase-conjugated secondary antibody (Sigma-Aldrich A3687). Signal amplitude was quantified using the GelPro 3.2 software (Bio-Rad).

Measurements of photosynthetic activity. The oxygen evolution activity of the cultures was measured at $25^{\circ} \mathrm{C}$ with a Clark-type $\mathrm{O}_{2}$ electrode (Hansatech, UK) upon illumination with white light provided by a halogen lamp (Schott, Germany). Samples of $2 \mathrm{~mL}$ cell suspension $\left(5 \times 10^{6}\right.$ cell $\left.\mathrm{mL}^{-1}\right)$ were loaded into the oxygen electrode chamber; $3 \mathrm{mM}$ $\mathrm{NaHCO}_{3}$ was added to the cell suspension prior to the $\mathrm{O}_{2}$ evolution measurements to ensure electron transport was not limited by the carbon supply.

In vivo chlorophyll fluorescence analysis. Fluorescence induction kinetics were recorded with a home-built apparatus, as previously described [99]. Variable fluorescence was induced with a green light of $15 \mu \mathrm{mol}$ photons $\mathrm{m}^{-2} \mathrm{~s}^{-1}$ at RT, on cells suspensions $\left(1 \times 10^{7}\right.$ cells $\left.\mathrm{mL}^{-1}\right)$ in BG-11 medium containing $50 \mu \mathrm{M}$ DCMU. The reciprocal of time corresponding to two-thirds of the fluorescence rise $\left(\mathrm{T}_{2 / 3}\right)$ was taken as a measure of the PSII functional antenna size [42,43]. Maximum quantum efficiency of PSII $\left(\mathrm{F}_{\mathrm{v}} / \mathrm{F}_{\mathrm{m}}\right)$ [100] was measured on cell suspension with a PAM 101 fluorimeter (Heinz-Walz, Effeltrich, Germany). The light dependence of NPQ was measured through Chl fluorescence with a Fluor-Cam 700MF (PSI, Drasov, Czech Republic), on cell suspension dark-adapted for $2 \mathrm{~h}$ at RT; NPQ was assessed at steady-state photosynthesis, upon 25 min illumination over a range of light intensities (100-1400 $\mu \mathrm{mol}$ photons $\mathrm{m}^{-2} \mathrm{~s}^{-1}$ ).

Determination of the sensitivity to photooxidative stress. The extent of lipid peroxidation in cells was estimated by measuring malondialdehyde (MDA) formation, as an indirect quantification of lipid peroxides. Quantitative evaluation was done by transferring aliquots of WT and mutant cell suspensions in BG-11, corresponding to $4 \times 10^{6}$ cells $\mathrm{mL}^{-1}$, into a 24- 
well culture plate, $2 \mathrm{~mL}$ total volume in each well, kept on a rotary shaker and illuminated for 2 days with high light $\left(1400 \mu \mathrm{mol}\right.$ photons $\left.\mathrm{m}^{-2} \mathrm{~s}^{-1}, 20^{\circ} \mathrm{C}\right)$. Samples $\left(2 \times 10^{5}\right.$ cells $)$ were taken for analysis for a period of $48 \mathrm{~h}$, and frozen in liquid nitrogen. MDA content of aliquots was quantified as previously described [101].

The photobleaching kinetics of $\mathrm{Chl}$ cell content were measured on cell suspensions $\left(2 \times 10^{6}\right.$ cells $\mathrm{mL}^{-1}$, in BG-11 $+0.03 \% w / v$ agarose $)$ using actinic light intensities of $14,000 \mu \mathrm{mol}$ of photons $\mathrm{m}^{-2} \mathrm{~s}^{-1}$ for $2 \mathrm{~h}$; temperature of samples was maintained at $20{ }^{\circ} \mathrm{C}$. During the illumination, the absorbance area between $600-750 \mathrm{~nm}$ was recorded; the initial and maximal absorbance were set, so the same absorbance area was used in the wavelength range $600 \mathrm{~nm}<\lambda<750 \mathrm{~nm}$ for all the samples.

Growth analysis. Growth experiments were performed at $25^{\circ} \mathrm{C}$ in a home-built photobioreactor, composed of glass cylinders with a maximum light path of $8 \mathrm{~cm}$ and a working volume of 1 liter each [47]. Cultures were continuously mixed with a flux of air and $\mathrm{CO}_{2}$. The ratio of compressed air and $\mathrm{CO}_{2}$ was automatically adjusted to keep the $\mathrm{pH}$ of the medium within the range of 6.8-7.2. Each autotrophic batch cultivation was carried out in duplicate. Illumination was provided by a panel of warm-white LEDs (Epistar 35mil Chip High Power LED, warm white LEDE-P20B-DW), microalgae were exposed to irradiance of $1400 \mu \mathrm{mol}$ photons $\mathrm{m}^{-2} \mathrm{~s}^{-1}$, with a photoperiod of $16 / 8 \mathrm{~h}$ light/dark; batch cultivation was carried out in duplicate.

For cultivation under very strong irradiance $\left(2500 \mu \mathrm{mol}\right.$ photons $\left.\mathrm{m}^{-2} \mathrm{~s}^{-1}\right)$, illumination was provided by a panel of warm-white LEDs (Epistar 35mil Chip High Power LED, warm white LEDE-P20B-DW), microalgae shaked in flasks were exposed to an irradiance of $2500 \mu \mathrm{mol}$ photons $\mathrm{m}^{-2} \mathrm{~s}^{-1}$, with a photoperiod of $16 / 8 \mathrm{~h}$ light/dark; batch cultivation was carried out in triplicate. The parameters determined to monitor cell growth were cell number and dry biomass weight, for which the washed cell pellets were dried overnight in a lyophilizer.

Determination of total lipid content. Total lipids were extracted from $100 \mathrm{mg}$ homogenized biomass ( 4 cycles of $30 \mathrm{~s}$ at $8000 \mathrm{rpm}$, with a Precellys homogenizer, Bertin, France) using an extraction protocol by [102], with a total of $3 \mathrm{~mL}$ methanol, $6 \mathrm{~mL}$ chloroform, and a subsequent washing step with $4 \mathrm{~mL}$ water. Net total lipid amount was determined gravimetrically.

Whole-genome sequencing and identification of unique mutations. For DNA preparation, $2 \times 10^{8}$ cells were collected by centrifugation, then resuspended in $1 \mathrm{ml}$ TEN buffer $(10 \mathrm{mM}$ Tris- $\mathrm{HCl} \mathrm{pH}$ 8.0, $100 \mathrm{mM}$ EDTA, $150 \mathrm{mM} \mathrm{NaCl})$, centrifuged $\left(1500 \times g, 2 \mathrm{~min}, 4^{\circ} \mathrm{C}\right)$ and resuspended in $300 \mu \mathrm{L}$ SDS-EB buffer ( $2 \% w / v$ SDS, $400 \mathrm{mM} \mathrm{NaCl}, 40 \mathrm{mM}$ EDTA, $100 \mathrm{mM}$ Tris- $\mathrm{HCl} \mathrm{pH} \mathrm{8.0).} \mathrm{Extraction} \mathrm{by} \mathrm{mechanical} \mathrm{destruction} \mathrm{was} \mathrm{carried} \mathrm{out} \mathrm{by} \mathrm{treating} \mathrm{the} \mathrm{sus-}$ pensions in Precellys Homogenizer (Bertin Instruments) with $100 \mathrm{mg}$ glass beads (8 cycles, $30 \mathrm{~s}$ each cycle, $8000 \mathrm{rpm}$ ). Samples were treated with $700 \mu \mathrm{L}$ phenol:chloroform:isoamyl alcohol (25:24:1), centrifuged $\left(15,000 \times g, 5 \mathrm{~min}, 4{ }^{\circ} \mathrm{C}\right)$, then 2.5 volumes of ethanol and 0.11 volumes of $\mathrm{Na}$-acetate $3 \mathrm{M} \mathrm{pH} 5.5$ were added to the supernatant. Upon incubation at $-80{ }^{\circ} \mathrm{C}$ for $30 \mathrm{~min}$, DNA was precipitated $\left(15,000 \times \mathrm{g}, 25 \mathrm{~min}, 4^{\circ} \mathrm{C}\right)$ and washed twice with $600 \mu \mathrm{L}$ ethanol. Pellets were resuspended in a small volume of $10 \mathrm{mM}$ Tris- $\mathrm{HCl}$ buffer $\mathrm{pH} 8.0$, treated with RNAse $10 \mu \mathrm{g} / \mu \mathrm{L}$ at $37^{\circ} \mathrm{C}$ for $30 \mathrm{~min}$, then DNA was further purified from RNA contaminants (NucleoSpin Plasmid, MACHEREY-NAGEL). DNA samples were quantified by Qubit 2.0 Fluorometer (Invitrogen, Carlsbad, CA, USA). Celero DNA-Seq Library Preparation Kit (Tecan Genomics, Redwood City, CA, USA) has been used for library preparation following the manufacturer's instructions. Final libraries were checked with both Qubit 2.0 Fluorometer (Invitrogen, Carlsbad, CA, USA) and Agilent 2100 Bioanalyzer DNA assay (Agilent technologies, Santa Clara, CA, USA). Libraries were then pooled for sequencing and sequenced in paired-end 125 bp mode on HiSeq2500 (Illumina, San Diego, CA, USA). Sequencing was outsourced (https:/ / www.igatechnology.com, accessed on 1 May 2021).

Assessment of raw read quality was performed with FASTQC v0.11.9 (https:/ / www. bioinformatics.babraham.ac.uk/projects/fastqc/, accessed on 1 May 2021). All sequences 
were trimmed with Trimmomatic v0.39 [103]. Alignments were performed with BurrowsWheeler Aligner (BWA) v0.7.17 [104] using default parameters for paired-end reads and mapped to the recently published reference genome [105]. Sorting and deduplication were performed with PicardTools v2.17.10 (http:/ / broadinstitute.github.io/picard, accessed on 1 May 2021). Statistical analysis of BAM files was performed with QualiMap v2.2.2 [106]. SNPs and small indels were called using the GATK Haplotype Caller v4.0.6.0 [107] with ploidy set to 1 . All the filtering processes were carried out using GATK SelectVariants and VariantFilteration tools. First, common SNPs between each mutant and the parental WT were removed from the dataset. The Quality by Depth filter with a cut-off of $\mathrm{QD}<2.0$ was used to filter out variants with low confidence. In addition, Chlorella vulgaris is haploid and heterozygous sites likely represent alignment or sequencing errors. Therefore, heterozygous variants in each sample with an allele frequency below 0.9 were removed. Finally, variants were manually inspected using the Integrated Genomics Viewer (IGV) v2.3 [108]. SnpEff v4.3 [109] was used to retrieve the genomic context of each variant and predict the effect of the variants on gene function. Functional information for the identified genes was obtained through Blast2go analysis [110]. Protein domains and motifs were predicted by InterPro and its associated software [111]. SIFT 4G (Sorting Intolerant From Tolerant for Genomes) algorithm v2.0.0 [112] was used to build SIFT4G database for Chlorella vulgaris genome. SIFT 4G annotator (https:/ / github.com/pauline-ng/SIFT4G_Annotator, accessed on 1 May 2021) was used to annotate the VCF file. TargetP v2.0 [113] and ChloroP v1.1 [114] were used to detect sequence signals.

Supplementary Materials: The following are available online at https:/ /www.mdpi.com/article/10 $.3390 /$ plants10050911/s1. Figure S1. Analysis of pigment content of WT and NFR cells, grown in either control or $\mathrm{N}$-depleted media. Pigment composition was determined after 5 days of growth in each medium (see Table 2). Separation of lipid-soluble pigments was based on HPLC analysis. Each chromatogram represents absorbance at $440 \mathrm{~nm}$ of pigments extracted in dimethyl-formamide from dark-adapted cells. Chromatograms were vertically shifted for better comparison. Figure S2. Effect of nitrogen starvation on WT and NFR mutants. (A) Cells were grown in BG-11 with 100\% content of nitrogen $\left(17 \mathrm{mM} \mathrm{NaNO}_{3}\right)$ till they reach saturation. Then the cells were collected by centrifugation and then resuspended in BG-11 with $5 \%$ content of nitrogen $\left(0.8 \mathrm{mM} \mathrm{NaNO}_{3}\right)$. Yellow circles represent the intracellular content in lipophilic compounds, such as TAGs and carotenoids, whose accumulation is stimulated by factors such as irradiance and nutrient availability (see [75] in the main text). (B) Appearance of the three genotypes at the end of the experiment, after 5 days of growth in $\mathrm{N}$ depleted medium. All the lines were diluted at the same cellular concentration $\left(2 \times 10^{7}\right.$ cells $\left.\mathrm{mL}^{-1}\right)$. Figure S3. Growth of WT and NFR strains under low light conditions. (A) Growth curves of WT and NRF mutant lines under photoautotrophic conditions, monitored as the cell number per $\mathrm{ml}$ culture. All experiments were performed in flasks with continuous stirring, illuminated with $70 \mu \mathrm{mol}$ photons $\mathrm{m}^{-2} \mathrm{~s}^{-1}, 25^{\circ} \mathrm{C}$. Cell concentration at $\mathrm{t}_{0}$ was about $1 \times 10^{6}$ cells $\mathrm{mL}^{-1}$. (B) Fresh weight (FW) of biomass collected after 9 days of growth. Symbols and error bars show means \pm SD, $n=5$. Values marked with different letters are significantly different from each other (ANOVA, $p<0.05$ ). Figure S4. Photoautotrophic growth of WT and NFR strains under excess light conditions. (A) Growth of WT and NRF mutant lines was monitored under autotrophic conditions, in flasks with continuous stirring, under strong light conditions $\left(2500 \mu \mathrm{mol}\right.$ photons $\left.\mathrm{m}^{-2} \mathrm{~s}^{-1}, 25^{\circ} \mathrm{C}\right)$, as the cell number per $\mathrm{ml}$ culture. At time 0 , the cultures were switched from low light $(70 \mu \mathrm{mol}$ photons $\mathrm{m}^{-2} \mathrm{~s}^{-1}, 25^{\circ} \mathrm{C}$ ) to strong light conditions. Cell concentration at $\mathrm{t}_{0}$ was about $1 \times 10^{6}$ cells $\mathrm{mL}^{-1}$. (B) fresh weight (FW) of biomass collected after 6 days of growth. Symbols and error bars show means $\pm \mathrm{SD}, n=5$. Values marked with different letters are significantly different from each other (ANOVA, $p<0.05$ ). Figure S5. Analysis of room temperature Chl fluorescence during photosynthesis. Chl fluorescence was monitored in cell suspensions from dark-adapted cultures (see methods for details). Cells were given $25 \mathrm{~min}$ of white light illumination, over a range of light intensities (white bar). Maximum fluorescence in the dark $\left(\mathrm{F}_{\mathrm{m}}\right.$, dark bar) and in the light $\left(\mathrm{F}_{\mathrm{m}}{ }^{\prime}\right.$, white bar) are shown as means $\pm \mathrm{SD}(n=4)$. Figure S6. Frequency of base changes in NFR mutants. EMS mutagenesis induces nucleotide transition, transversion, insertion and deletions. Higher frequency of G/C to $A / T$ transition corresponds to the expected EMS mutagenesis outcome with transitions as the predominant type of mutations. Supplementary Figure S7. Schematic representation of Glycerol-3-phosphate 
acyltransferase 3 (g4271) and predicted domains. (A) An overview of protein domains and motifs predicted by InterPro and its associated software. (B) The last two residues of the cytoplasmic domain are shaded light red (glutamic acid 178 and arginine 179). The site of mutation E178D overlaps with PANTHER entry PTHR23063:SF2, SUPERFAMILY entry SSF69593, and predicted cytoplasmic domain. (C) Amino acid sequence alignment of predicted cytoplasmic domain (2) and transmembrane domain (3) in Chlorella vulgaris Glycerol-3-phosphate acyltransferase 3 (g4271) and top BLAST hits in green algae (taxid:3041) with $\geq 75 \%$ coverage. The position of Glu178Asp mutation present in both NFR-13 and NFR-3 mutants is indicated by an inverted red triangle. The cytoplasmic domain in Chlorella vulgaris is indicated by teal color while the transmembrane domain is in orange. Black boxes indicate $\geq 80 \%$ sequence identity. Supplementary Table S1. Lipid content of algal biomass. Total lipid content was determined gravimetrically on the dry biomass, from WT and mutant cultures grown for 7 days in nutrient-rich BG-11 medium $\left(1400 \mu\right.$ mol photons $\left.\mathrm{m}^{-2} \mathrm{~s}^{-1}, 25^{\circ} \mathrm{C}\right)$ and then moved for further 4 days of growth in modified BG-11 medium with limiting N source. Data are expressed as mean $\pm \mathrm{SD}, n=4$. Significant different values in oil content among genotypes (ANOVA test, $p<0.05)$ are marked with different letters.

Author Contributions: L.D. and R.B. conceived this work. Z.G., S.C. and S.B. identified mutant lines and performed all biochemical and physiological characterizations under the supervision of R.B., and L.D., M.J. and N.V. performed the bioinformatic analysis. L.D. and R.B. wrote the manuscript with contributions from all the authors. All authors have read and agreed to the published version of the manuscript.

Funding: We acknowledge the financial support from the University-Industry Joint Projects "Industrialgae" (grant JPVR 2016). In addition, we acknowledge the support of the ENAC-2019 fund "Carburanti Alternativi per 1'Aviazione Civile" and the grant PON for industrial research and experimental development ARS01_00881 “ORIGAMI” by the Italian Ministry of University and Research (MIUR).

Institutional Review Board Statement: Not applicable.

Informed Consent Statement: Not applicable.

Data Availability Statement: Not applicable.

Conflicts of Interest: The authors declare no conflict of interest.

\section{References}

1. Benedetti, M.; Vecchi, V.; Barera, S.; Dall'Osto, L. Biomass from microalgae: The potential of domestication towards sustainable biofactories. Microb. Cell Fact. 2018, 17, 173. [CrossRef] [PubMed]

2. Nelson, N.; Ben-Shem, A. The complex architecture of oxygenic photosynthesis. Nat. Rev. Mol. Cell Biol. 2004, 5, 239-250. [CrossRef]

3. Weyer, K.M.; Bush, D.R.; Darzins, A.; Willson, B.D. Theoretical maximum algal oil production. Bioenergy Res. 2010, 3, 204-213. [CrossRef]

4. Chisti, Y. Biodiesel from microalgae. Biotechnol. Adv. 2007, 25, 294-306. [CrossRef]

5. Rodolfi, L.; Chini Zittelli, G.; Bassi, N.; Padovani, G.; Biondi, N.; Bonini, G.; Tredici, M.R. Microalgae for oil: Strain selection, induction of lipid synthesis and outdoor mass cultivation in a low-cost photobioreactor. Biotechnol. Bioeng. 2009, 102, 100-112. [CrossRef] [PubMed]

6. Woittiez, L.S.; van Wijk, M.T.; Slingerland, M.; van Noordwijk, M.; Giller, K.E. Yield gaps in oil palm: A quantitative review of contributing factors. Eur. J. Agron. 2017, 83, 57-77. [CrossRef]

7. Leu, S.; Boussiba, S. Advances in the Production of High-Value Products by Microalgae. Ind. Biotechnol. 2014, 10, 169-183. [CrossRef]

8. Chew, K.W.; Yap, J.Y.; Show, P.L.; Suan, N.H.; Juan, J.C.; Ling, T.C.; Lee, D.-J.; Chang, J.-S. Microalgae biorefinery: High value products perspectives. Bioresour. Technol. 2017, 229, 53-62. [CrossRef]

9. Scott, S.A.; Davey, M.P.; Dennis, J.S.; Horst, I.; Howe, C.J.; Lea-Smith, D.J.; Smith, A.G. Biodiesel from algae: Challenges and prospects. Curr. Opin. Biotechnol. 2010, 21, 277-286. [CrossRef] [PubMed]

10. Christenson, L.; Sims, R. Production and harvesting of microalgae for wastewater treatment, biofuels, and bioproducts. Biotechnol. Adv. 2011, 29, 686-702. [CrossRef] [PubMed]

11. Pittman, J.K.; Dean, A.P.; Osundeko, O. The potenrial of sustainable algal biofuel production using wastewater resources. Bioresour. Technol. 2011, 102, 17-25. [CrossRef]

12. Munkel, R.; Schmid-Staiger, U.; Werner, A.; Hirth, T. Optimization of outdoor cultivation in flat panel airlift reactors for lipid production by Chlorella vulgaris. Biotechnol. Bioeng. 2013, 110, 2882-2893. [CrossRef] [PubMed] 
13. Borowitzka, M.A. High-value products from microalgae-Their development and commercialisation. J. Appl. Phycol. 2013, 25, 743-756. [CrossRef]

14. Chen, J.H.; Chen, C.Y.; Hasunuma, T.; Kondo, A.; Chang, C.H.; Ng, I.S.; Chang, J.S. Enhancing lutein production with mixotrophic cultivation of Chlorella sorokiniana MB-1-M12 using different bioprocess operation strategies. Bioresour. Technol. 2019, $278,17-25$. [CrossRef] [PubMed]

15. Novoveská, L.; Ross, M.E.; Stanley, M.S.; Pradelles, R.; Wasiolek, V.; Sassi, J.F. Microalgal carotenoids: A review of production, current markets, regulations, and future direction. Mar. Drugs 2019, 17, 640. [CrossRef]

16. Nwachukwu, I.D.; Udenigwe, C.C.; Aluko, R.E. Lutein and zeaxanthin: Production technology, bioavailability, mechanisms of action, visual function, and health claim status. Trends Food Sci. Technol. 2016, 49, 74-84. [CrossRef]

17. Chia, S.R.; Chew, K.W.; Show, P.L.; Yap, Y.J.; Ong, H.C.; Ling, T.C.; Chang, J.S. Analysis of Economic and Environmental Aspects of Microalgae Biorefinery for Biofuels Production: A Review. Biotechnol. J. 2018, 13. [CrossRef] [PubMed]

18. Tredici, M.R. Photobiology of microalgae mass cultures: Understanding the tools for the next green revolution. Biofuels 2010, 1, 143-162. [CrossRef]

19. Heaton, E.A.; Dohleman, F.G.; Long, S.P. Meeting US biofuel goals with less land: The potential of Miscanthus. Glob. Chang. Biol. 2008, 14, 2000-2014. [CrossRef]

20. Stephenson, P.G.; Moore, C.M.; Terry, M.J.; Zubkov, M.V.; Bibby, T.S. Improving photosynthesis for algal biofuels: Toward a green revolution. Trends Biotechnol. 2011, 29, 615-623. [CrossRef]

21. Ooms, M.D.; Dinh, C.T.; Sargent, E.H.; Sinton, D. Photon management for augmented photosynthesis. Nat. Commun. 2016, 7 , 12699. [CrossRef]

22. Ruban, A.V.; Johnson, M.P.; Duffy, C.D.P. The photoprotective molecular switch in the photosystem II antenna. Biochim. Biophys. Acta Bioenerg. 2012, 1817, 167-181. [CrossRef] [PubMed]

23. Dall'Osto, L.; Bressan, M.; Bassi, R. Biogenesis of light harvesting proteins. Biochim. Biophys. Acta Bioenerg. 2015, 1847, 861-871. [CrossRef] [PubMed]

24. Fuciman, M.; Enriquez, M.M.; Polívka, T.; Dallosto, L.; Bassi, R.; Frank, H.A. Role of xanthophylls in light harvesting in green plants: A Spectroscopic investigation of mutant LHCII and Lhcb pigment-protein complexes. J. Phys. Chem. B 2012, 116, 3834-3849. [CrossRef] [PubMed]

25. Formighieri, C.; Franck, F.; Bassi, R. Regulation of the pigment optical density of an algal cell: Filling the gap between photosynthetic productivity in the laboratory and in mass culture. J. Biotechnol. 2012, 162, 115-123. [CrossRef] [PubMed]

26. Krieger-Liszkay, A.; Fufezan, C.; Trebst, A. Singlet oxygen production in photosystem II and related protection mechanism. Photosynth. Res. 2008, 98, 551-564. [CrossRef]

27. Aro, E.M.; Virgin, I.; Andersson, B. Photoinhibition of Photosystem II. Inactivation, protein damage and turnover. BBA Bioenerg. 1993, 1143, 113-134. [CrossRef]

28. Vecchi, V.; Barera, S.; Bassi, R.; Dall'osto, L. Potential and challenges of improving photosynthesis in algae. Plants 2020, 9, 67. [CrossRef]

29. Melis, A. Solar energy conversion efficiencies in photosynthesis: Minimizing the chlorophyll antennae to maximize efficiency. Plant Sci. 2009, 177, 272-280. [CrossRef]

30. Kulheim, C.; Agren, J.; Jansson, S. Rapid Regulation of Light Harvesting and Plant Fitness in the Field. Science 2002, 297, 91-93. [CrossRef]

31. Zhu, X.G.; Ort, D.R.; Whitmarsh, J.; Long, S.P. The slow reversibility of photosystem II thermal energy dissipation on transfer from high to low light may cause large losses in carbon gain by crop canopies: A theoretical analysis. J. Exp. Bot. 2004, 55, 1167-1175. [CrossRef] [PubMed]

32. Frank, H.A.; Cogdell, R.J. Carotenoids in photosynthesis. Photochem. Photobiol. 1996, 63, 257-264. [CrossRef]

33. Dall'Osto, L.; Piques, M.; Ronzani, M.; Molesini, B.; Alboresi, A.; Cazzaniga, S.; Bassi, R. The Arabidopsis nox mutant lacking carotene hydroxylase activity reveals a critical role for xanthophylls in photosystem I biogenesis. Plant Cell 2013, 25, 591-608. [CrossRef]

34. El Agamey, A.; Lowe, G.M.; McGarvey, D.J.; Mortensen, A.; Phillip, D.M.; Truscott, T.G.; Young, A.J. Carotenoid radical chemistry and antioxidant/pro-oxidant properties. Arch. Biochem. Biophys. 2004, 430, 37-48. [CrossRef]

35. Dall'Osto, L.; Holt, N.E.; Kaligotla, S.; Fuciman, M.; Cazzaniga, S.; Carbonera, D.; Frank, H.A.; Alric, J.; Bassi, R. Zeaxanthin protects plant photosynthesis by modulating chlorophyll triplet yield in specific light-harvesting antenna subunits. J. Biol. Chem. 2012, 287, 41820-41834. [CrossRef] [PubMed]

36. Dall'Osto, L.; Cazzaniga, S.; Guardini, Z.; Barera, S.; Benedetti, M.; Mannino, G.; Maffei, M.E.; Bassi, R. Combined resistance to oxidative stress and reduced antenna size enhance light-to-biomass conversion efficiency in Chlorella vulgaris cultures. Biotechnol. Biofuels 2019, 12, 221. [CrossRef]

37. Day, J.G.; Slocombe, S.P.; Stanley, M.S. Overcoming biological constraints to enable the exploitation of microalgae for biofuels. Bioresour. Technol. 2012, 109, 245-251. [CrossRef]

38. Dall'Osto, L.; Bassi, R.; Ruban, A. V Photoprotective Mechanisms: Carotenoids. In Advances in Plant Biology 5; Theg, S.M., Wollman, F.-A., Eds.; Plastid Biology; Springer Science+Business Media: New York, NY, USA, 2014; pp. $393-435$. 
39. Cordero, B.F.; Obraztsova, I.; Couso, I.; Leon, R.; Vargas, M.A.; Rodriguez, H. Enhancement of Lutein Production in Chlorella sorokiniana (Chorophyta) by Improvement of Culture Conditions and Random Mutagenesis. Mar. Drugs 2011, 9, 1607-1624. [CrossRef]

40. Chamovitz, D.; Pecker, I.; Hirschberg, J. The molecular basis of resistance to the herbicide norflurazon. Plant Mol. Biol. 1991, 16, 967-974. [CrossRef]

41. Del Campo, J.A.; García-González, M.; Guerrero, M.G. Outdoor cultivation of microalgae for carotenoid production: Current state and perspectives. Appl. Microbiol. Biotechnol. 2007, 74, 1163-1174. [CrossRef]

42. Malkin, S.; Armond, P.A.; Mooney, H.A.; Fork, D.C. Photosystem II photosynthetic unit sizes from fluorescence induction in leaves. Correlation to photosynthetic capacity. Plant Physiol. 1981, 67, 570-579. [CrossRef]

43. De Marchin, T.; Ghysels, B.; Nicolay, S.; Franck, F. Analysis of PSII antenna size heterogeneity of Chlamydomonas reinhardtii during state transitions. Biochim. Biophys. Acta Bioenerg. 2014, 1837, 121-130. [CrossRef]

44. Prasad, A.; Ferretti, U.; Sedlaová, M.; Pospíšil, P. Singlet oxygen production in Chlamydomonas reinhardtii under heat stress. Sci. Rep. 2016, 6. [CrossRef]

45. Del Campo, J.A.; Rodríguez, H.; Moreno, J.; Vargas, M.Á.; Rivas, J.; Guerrero, M.G. Accumulation of astaxanthin and lutein in Chlorella zofingiensis (Chlorophyta). Appl. Microbiol. Biotechnol. 2004, 64, 848-854. [CrossRef]

46. Kirst, H.; Garcia-Cerdan, J.G.; Zurbriggen, A.; Ruehle, T.; Melis, A. Truncated Photosystem Chlorophyll Antenna Size in the Green Microalga Chlamydomonas reinhardtii upon Deletion of the TLA3-CpSRP43 Gene. Plant Physiol. 2012, 160, $2251-2260$. [CrossRef]

47. Cazzaniga, S.; Dall'Osto, L.; Szaub, J.; Scibilia, L.; Ballottari, M.; Purton, S.; Bassi, R. Domestication of the green alga Chlorella sorokiniana: Reduction of antenna size improves light-use efficiency in a photobioreactor. Biotechnol. Biofuels $2014,7,157$. [CrossRef]

48. Perin, G.; Bellan, A.; Segalla, A.; Meneghesso, A.; Alboresi, A.; Morosinotto, T. Generation of random mutants to improve light-use efficiency of Nannochloropsis gaditana cultures for biofuel production. Biotechnol. Biofuels 2015, 8, 161. [CrossRef]

49. Niyogi, K.K. Safety valves for photosynthesis. Curr. Opin. Plant Biol. 2000, 3, 455-460. [CrossRef]

50. Park, S.; Steen, C.J.; Lyska, D.; Fischer, A.L.; Endelman, B.; Iwai, M.; Niyogi, K.K.; Fleming, G.R. Chlorophyll-carotenoid excitation energy transfer and charge transfer in Nannochloropsis oceanica for the regulation of photosynthesis. Proc. Natl. Acad. Sci. USA 2019, 116, 3385-3390. [CrossRef]

51. Solovchenko, A.; Khozin-Goldberg, I.; Recht, L.; Boussiba, S. Stress-induced changes in optical properties, pigment and fatty acid content of Nannochloropsis sp.: Implications for non-destructive assay of total fatty acids. Mar. Biotechnol. 2011, 13, 527-535. [CrossRef]

52. Hu, Q.; Sommerfeld, M.; Jarvis, E.; Ghirardi, M.; Posewitz, M.; Seibert, M.; Darzins, A. Microalgal triacylglycerols as feedstocks for biofuel production: Perspectives and advances. Plant J. 2008, 54, 621-639. [CrossRef]

53. Menon, K.R.; Balan, R.; Suraishkumar, G.K. Stress induced lipid production in Chlorella vulgaris: Relationship with specific intracellular reactive species levels. Biotechnol. Bioeng. 2013, 110, 1627-1636. [CrossRef]

54. Gimpel, J.A.; Henríquez, V.; Mayfield, S.P. In Metabolic Engineering of Eukaryotic Microalgae: Potential and Challenges Come with Great Diversity. Front. Microbiol. 2015, 6. [CrossRef]

55. Richmond, A.; Cheng-Wu, Z.; Zarmi, Y. Efficient use of strong light for high photosynthetic productivity: Interrelationships between the optical path, the optimal population density and cell-growth inhibition. In Proceedings of the Biomolecular Engineering; Elsevier: Amsterdam, The Netherlands, 2003; Volume 20, pp. 229-236.

56. Polle, J.E.W.; Kanakagiri, S.-D.; Melis, A. tla1, a DNA insertional transformant of the green alga Chlamydomonas reinhardtii with a truncated light-harvesting chlorophyll antenna size. Planta 2003, 217, 49-59. [CrossRef]

57. Yang, Y.; Gao, K. Effects of $\mathrm{CO}_{2}$ concentrations on the freshwater microalgae, Chlamydomonas reinhardtii, Chlorella pyrenoidosa and Scenedesmus obliquus (Chlorophyta). J. Appl. Phycol. 2003, 15, 379-389. [CrossRef]

58. Domingues, N.; Matos, A.R.; da Silva, J.M.; Cartaxana, P. Response of the Diatom Phaeodactylum tricornutum to photooxidative stress resulting from high light exposure. PLoS ONE 2012, 7, e38162. [CrossRef]

59. Carvalho, A.P.; Silva, S.O.; Baptista, J.M.; Malcata, F.X. Light requirements in microalgal photobioreactors: An overview of biophotonic aspects. Appl. Microbiol. Biotechnol. 2011, 89, 1275-1288. [CrossRef]

60. Tikkanen, M.; Grieco, M.; Nurmi, M.; Rantala, M.; Suorsa, M.; Aro, E.M. Regulation of the photosynthetic apparatus under fluctuating growth light. Philos. Trans. R. Soc. B-Biol. Sci. 2012, 367, 3486-3493. [CrossRef]

61. Li, Z.R.; Wakao, S.; Fischer, B.B.; Niyogi, K.K. Sensing and responding to excess Light. Ann. Rev. Plant Biol. 2009, 60, 239-260. [CrossRef]

62. Havaux, M.; Dall'Osto, L.; Bassi, R. Zeaxanthin has enhanced antioxidant capacity with respect to all other xanthophylls in Arabidopsis leaves and functions independent of binding to PSII antennae. Plant Physiol. 2007, 145, 1506-1520. [CrossRef]

63. Erickson, E.; Wakao, S.; Niyogi, K.K. Light stress and photoprotection in Chlamydomonas reinhardtii. Plant J. 2015, 82, 449-465. [CrossRef]

64. Meagher, E.; Rangsrikitphoti, P.; Faridi, B.; Zamzam, G.; Durnford, D.G. Photoacclimation to high-light stress in Chlamydomonas reinhardtii during conditional senescence relies on generating $\mathrm{pH}$-dependent, high-quenching centres. Plant Physiol. Biochem. 2021, 158, 136-145. [CrossRef] 
65. Kondo, T.; Pinnola, A.; Chen, W.J.; Dall'Osto, L.; Bassi, R.; Schlau-Cohen, G.S. Single-molecule spectroscopy of LHCSR1 protein dynamics identifies two distinct states responsible for multi-timescale photosynthetic photoprotection. Nat. Chem. 2017, 9, 772. [CrossRef]

66. Baroli, I.; Gutman, B.L.; Ledford, H.K.; Shin, J.W.; Chin, B.L.; Havaux, M.; Niyogi, K.K. Photo-oxidative stress in a xanthophylldeficient mutant of Chlamydomonas. J. Biol. Chem. 2004, 279, 6337-6344. [CrossRef]

67. Fiore, A.; Dall'Osto, L.; Cazzaniga, S.; Diretto, G.; Giuliano, G.; Bassi, R. A quadruple mutant of Arabidopsis reveals a $\beta$-carotene hydroxylation activity for LUT1/CYP97C1 and a regulatory role of xanthophylls on determination of the PSI/PSII ratio. BMC Plant Biol. 2012, 12, 50. [CrossRef] [PubMed]

68. Ledford, H.K.; Chin, B.L.; Niyogi, K.K. Acclimation to singlet oxygen stress in Chlamydomonas reinhardtii. Eukaryot.Cell 2007, 6, 919-930. [CrossRef]

69. Shao, N.; Krieger-Liszkay, A.; Schroda, M.; Beck, C.F. A reporter system for the individual detection of hydrogen peroxide and singlet oxygen: Its use for the assay of reactive oxygen species produced in vivo. Plant J. 2007, 50, 475-487. [CrossRef] [PubMed]

70. Fischer, B.B.; Dayer, R.; Schwarzenbach, Y.; Lemaire, S.D.; Behra, R.; Liedtke, A.; Eggen, R.I.L. Function and regulation of the glutathione peroxidase homologous gene GPXH/GPX5 in Chlamydomonas reinhardtii. Plant Mol. Biol. 2009, 71, 569-583. [CrossRef]

71. Kleine, T.; Leister, D. Retrograde signaling: Organelles go networking. Biochim. Biophys. Acta Bioenerg. 2016, 1857, 1313-1325. [CrossRef]

72. Ramel, F.; Birtic, S.; Ginies, C.; Soubigou-Taconnat, L.; Triantaphylides, C.; Havaux, M. Carotenoid oxidation products are stress signals that mediate gene responses to singlet oxygen in plants. Proc. Natl. Acad. Sci. USA 2012, 109, 5535-5540. [CrossRef]

73. D'Alessandro, S.; Havaux, M. Sensing $\beta$-carotene oxidation in photosystem II to master plant stress tolerance. New Phytol. 2019, 223, 1776-1783. [CrossRef] [PubMed]

74. García-Plazaola, J.I.; Portillo-Estrada, M.; Fernández-Marín, B.; Kännaste, A.; Niinemets, Ü. Emissions of carotenoid cleavage products upon heat shock and mechanical wounding from a foliose lichen. Environ. Exp. Bot. 2017, 133, 87-97. [CrossRef]

75. Wase, N.; Black, P.N.; Stanley, B.A.; Dirusso, C.C. Integrated quantitative analysis of nitrogen stress response in Chlamydomonas reinhardtii using metabolite and protein profiling. J. Proteome Res. 2014, 13, 1373-1396. [CrossRef] [PubMed]

76. Guarnieri, M.T.; Nag, A.; Smolinski, S.L.; Darzins, A.; Seibert, M.; Pienkos, P.T. Examination of triacylglycerol biosynthetic pathways via de novo transcriptomic and proteomic analyses in an unsequenced microalga. PLoS ONE 2011, 6, e25851. [CrossRef]

77. Jacquier, N.; Choudhary, V.; Mari, M.; Toulmay, A.; Reggiori, F.; Schneiter, R. Lipid droplets are functionally connected to the endoplasmic reticulum in Saccharomyces cerevisiae. J. Cell Sci. 2011, 124, 2424-2437. [CrossRef] [PubMed]

78. Sahni, P.; Aggarwal, P.; Sharma, S.; Singh, B. Nuances of microalgal technology in food and nutraceuticals: A review. Nutr. Food Sci. 2019, 49, 866-885. [CrossRef]

79. Lafarga, T. Effect of microalgal biomass incorporation into foods: Nutritional and sensorial attributes of the end products. Algal Res. 2019, 41, 101566. [CrossRef]

80. Zimny, T.; Sowa, S.; Tyczewska, A.; Twardowski, T. Certain new plant breeding techniques and their marketability in the context of EU GMO legislation-Recent developments. New Biotechnol. 2019, 51, 49-56. [CrossRef]

81. Del Campo, J.A.; Moreno, J.; Rodríguez, H.; Angeles Vargas, M.; Rivas, J.; Guerrero, M.G. Carotenoid content of chlorophycean microalgae: Factors determining lutein accumulation in Muriellopsis sp. (Chlorophyta). J. Biotechnol. 2000, 76, 51-59. [CrossRef]

82. Janßen, H.J.; Steinbüchel, A. Fatty acid synthesis in Escherichia coli and its applications towards the production of fatty acid based biofuels. Biotechnol. Biofuels 2014, 7. [CrossRef] [PubMed]

83. Wu, T.; Ye, L.; Zhao, D.; Li, S.; Li, Q.; Zhang, B.; Bi, C.; Zhang, X. Membrane engineering-A novel strategy to enhance the production and accumulation of $\beta$-carotene in Escherichia coli. Metab. Eng. 2017, 43, 85-91. [CrossRef] [PubMed]

84. Ling, Q.; Huang, W.; Baldwin, A.; Jarvis, P. Chloroplast biogenesis is regulated by direct action of the ubiquitin-proteasome system. Science 2012, 338, 655-659. [CrossRef]

85. Ling, Q.; Jarvis, P. Regulation of chloroplast protein import by the ubiquitin E3 ligase SP1 is important for stress tolerance in plants. Curr. Biol. 2015, 25, 2527-2534. [CrossRef]

86. Formighieri, C.; Cazzaniga, S.; Kuras, R.; Bassi, R. Biogenesis of photosynthetic complexes in the chloroplast of Chlamydomonas reinhardtii requires ARSA1, a homolog of prokaryotic arsenite transporter and eukaryotic TRC40 for guided entry of tail-anchored proteins. Plant J. 2012, 73, 850-861. [CrossRef] [PubMed]

87. Farkas, I.; Dombrádi, V.; Miskei, M.; Szabados, L.; Koncz, C. Arabidopsis PPP family of serine/threonine phosphatases. Trends Plant Sci. 2007, 12, 169-176. [CrossRef] [PubMed]

88. Park, J.J.; Wang, H.; Gargouri, M.; Deshpande, R.R.; Skepper, J.N.; Holguin, F.O.; Juergens, M.T.; Shachar-Hill, Y.; Hicks, L.M.; Gang, D.R. The response of Chlamydomonas reinhardtii to nitrogen deprivation: A systems biology analysis. Plant J. 2015, 81, 611-624. [CrossRef]

89. Neily, M.H.; Matsukura, C.; Maucourt, M.; Bernillon, S.; Deborde, C.; Moing, A.; Yin, Y.G.; Saito, T.; Mori, K.; Asamizu, E.; et al. Enhanced polyamine accumulation alters carotenoid metabolism at the transcriptional level in tomato fruit over-expressing spermidine synthase. J. Plant Physiol. 2011, 168, 242-252. [CrossRef] [PubMed]

90. Nakai, A.; Yamauchi, Y.; Sumi, S.; Tanaka, K. Role of acylamino acid-releasing enzyme/oxidized protein hydrolase in sustaining homeostasis of the cytoplasmic antioxidative system. Planta 2012, 236, 427-436. [CrossRef] 
91. Angstenberger, M.; De Signori, F.; Vecchi, V.; Dall'Osto, L.; Bassi, R. Cell Synchronization Enhances Nuclear Transformation and Genome Editing via Cas9 Enabling Homologous Recombination in Chlamydomonas reinhardtii. ACS Synth. Biol. 2020, 9, 2840-2850. [CrossRef]

92. Li, X.; Patena, W.; Fauser, F.; Jinkerson, R.E.; Saroussi, S.; Meyer, M.T.; Ivanova, N.; Robertson, J.M.; Yue, R.; Zhang, R.; et al. A genome-wide algal mutant library and functional screen identifies genes required for eukaryotic photosynthesis. Nat. Genet. 2019, 51, 627-635. [CrossRef]

93. Kropat, J.; Hong-Hermesdorf, A.; Casero, D.; Ent, P.; Castruita, M.; Pellegrini, M.; Merchant, S.S.; Malasarn, D. A revised mineral nutrient supplement increases biomass and growth rate in Chlamydomonas reinhardtii. Plant J. 2011, 66, 770-780. [CrossRef] [PubMed]

94. Allen, M.M. Simple conditions for growth of unicellular blue-green algae on plates. J.Phycol. 1968, 4, 1-4. [CrossRef]

95. Gilmore, A.M.; Yamamoto, H.Y. Zeaxanthin formation and energy-dependent fluorescence quenching in pea chloroplasts under artificially mediated linear and cyclic electron transport. Plant Physiol. 1991, 96, 635-643. [CrossRef] [PubMed]

96. Croce, R.; Canino, G.; Ros, F.; Bassi, R. Chromophore organization in the higher-plant photosystem II antenna protein CP26. Biochemistry 2002, 41, 7334-7343. [CrossRef]

97. Schagger, H.; von Jagow, G. Tricine-sodium dodecyl sulfate-polyacrylamide gel electrophoresis for the separation of proteins in the range from 1 to $100 \mathrm{kDa}$. Anal. Biochem. 1987, 166, 368-379. [CrossRef]

98. Towbin, H.; Staehelin, T.; Gordon, J. Electrophoretic transfer of proteins from polyacrylamide gels to nitrocellulose sheets: Procedure and some applications. Proc. Natl. Acad. Sci. USA 1979, 76, 4350-4354. [CrossRef]

99. Rappaport, F.; Beal, D.; Joliot, A.; Joliot, P. On the advantages of using green light to study fluorescence yield changes in leaves. Biochim. Biophys. Acta 2007, 1767, 56-65. [CrossRef] [PubMed]

100. Maxwell, K.; Johnson, G.N. Chlorophyll fluorescence-A practical guide. J. Exp. Bot. 2000, 51, 659-668. [CrossRef]

101. Havaux, M.; Eymery, F.; Porfirova, S.; Rey, P.; Dormann, P. Vitamin E protects against photoinhibition and photooxidative stress in Arabidopsis thaliana. Plant Cell 2005, 17, 3451-3469. [CrossRef] [PubMed]

102. Axelsson, M.; Gentili, F. A single-step method for rapid extraction of total lipids from green microalgae. PLoS ONE 2014, 9 , e89643. [CrossRef]

103. Bolger, A.M.; Lohse, M.; Usadel, B. Trimmomatic: A flexible trimmer for Illumina sequence data. Bioinformatics 2014, 30, 2114-2120. [CrossRef]

104. Li, H.; Durbin, R. Fast and accurate short read alignment with Burrows-Wheeler transform. Bioinformatics 2009, 25, 1754-1760. [CrossRef]

105. Cecchin, M.; Marcolungo, L.; Rossato, M.; Girolomoni, L.; Cosentino, E.; Cuine, S.; Li-Beisson, Y.; Delledonne, M.; Ballottari, M. Chlorella vulgaris genome assembly and annotation reveals the molecular basis for metabolic acclimation to high light conditions. Plant J. 2019, 100, 1289-1305. [CrossRef]

106. García-Alcalde, F.; Okonechnikov, K.; Carbonell, J.; Cruz, L.M.; Götz, S.; Tarazona, S.; Dopazo, J.; Meyer, T.F.; Conesa, A. Qualimap: Evaluating next-generation sequencing alignment data. Bioinformatics 2012, 28, 2678-2679. [CrossRef] [PubMed]

107. Depristo, M.A.; Banks, E.; Poplin, R.; Garimella, K.V.; Maguire, J.R.; Hartl, C.; Philippakis, A.A.; Del Angel, G.; Rivas, M.A.; Hanna, M.; et al. A framework for variation discovery and genotyping using next-generation DNA sequencing data. Nat. Genet. 2011, 43, 491-501. [CrossRef] [PubMed]

108. Thorvaldsdóttir, H.; Robinson, J.T.; Mesirov, J.P. Integrative Genomics Viewer (IGV): High-performance genomics data visualization and exploration. Brief. Bioinform. 2013, 14, 178-192. [CrossRef] [PubMed]

109. Cingolani, P.; Platts, A.; Wang, L.L.; Coon, M.; Nguyen, T.; Wang, L.; Land, S.J.; Lu, X.; Ruden, D.M. A program for annotating and predicting the effects of single nucleotide polymorphisms, SnpEff: SNPs in the genome of Drosophila melanogaster strain w1118; iso-2; iso-3. Fly 2012, 6, 80-92. [CrossRef]

110. Götz, S.; García-Gómez, J.M.; Terol, J.; Williams, T.D.; Nagaraj, S.H.; Nueda, M.J.; Robles, M.; Talón, M.; Dopazo, J.; Conesa, A. High-throughput functional annotation and data mining with the Blast2GO suite. Nucleic Acids Res. 2008, 36, $3420-3435$. [CrossRef]

111. Mitchell, A.L.; Attwood, T.K.; Babbitt, P.C.; Blum, M.; Bork, P.; Bridge, A.; Brown, S.D.; Chang, H.Y.; El-Gebali, S.; Fraser, M.I.; et al. InterPro in 2019: Improving coverage, classification and access to protein sequence annotations. Nucleic Acids Res. 2019, 47, D351-D360. [CrossRef]

112. Vaser, R.; Adusumalli, S.; Leng, S.N.; Sikic, M.; Ng, P.C. SIFT missense predictions for genomes. Nat. Protoc. 2016, 11, 1-9. [CrossRef]

113. Armenteros, J.J.A.; Salvatore, M.; Emanuelsson, O.; Winther, O.; Von Heijne, G.; Elofsson, A.; Nielsen, H. Detecting sequence signals in targeting peptides using deep learning. Life Sci. Alliance 2019, 2. [CrossRef] [PubMed]

114. Emanuelsson, O.; Nielsen, H.; Heijne, G. Von ChloroP, a neural network-based method for predicting chloroplast transit peptides and their cleavage sites. Protein Sci. 1999, 8, 978-984. [CrossRef] [PubMed] 